\title{
Growth Regulation and Validation of Homogeneity in In Vitro-Derived Bleeding Heart by Molecular Markers and Spectral Analysis of Pigments
}

\author{
Dariusz Kulus $^{1}$ (1) . Jean de Dieu Muhire ${ }^{1} \cdot$ Barkin Aksoy $^{1}$
}

Received: 14 January 2020 / Accepted: 14 August 2020 / Published online: 4 September 2020

(c) The Author(s) 2020

\begin{abstract}
The aim of this study is to analyze the morphogenetic events in Lamprocapnos spectabilis (L.) Fukuhara (bleeding heart) 'Gold Heart' and 'White Gold' micropropagated in various culture media, and to evaluate the biochemical and genetic stability of the produced plants. None of the sixteen tested plant growth regulator (PGR) combinations improved the micropropagation efficiency or morphological traits of shoots in 'Gold Heart' compared to the PGRs-free control, indicating low intrinsic regenerability of this cultivar. As for bleeding heart 'White Gold', culture medium with $0.5 \mathrm{mg} \cdot \mathrm{L}^{-1} \mathrm{IBA}$ and $2.0 \mathrm{mg} \cdot \mathrm{L}^{-1} \mathrm{BA}$ was optimal in terms of multiplication ratio (9.8) and shoot parameters. Addition of PGRs was necessary for effective rooting in both cultivars studied. Some experimental combinations declined the concentration of chlorophylls and carotenoids in the shoots of bleeding heart, especially if a significant amount of callus was formed at the shoot base. The PGR-supplemented media stimulated the abundant secretion of phenols by shoots. The survival rate and quality of the plantlets after acclimatization varied from 0.0 to $100 \%$, depending on the composition of the multiplication medium. Plants with a higher number of leaves were more likely to survive acclimatization. Somaclonal variation was detected in 36.8 to even $69.1 \%$ of in vitro-derived plants by two genetic marker systems. Most of that variation was irrelevant, however, some genotypes were significantly different from the predominant control.
\end{abstract}

Keywords Acclimatization $\cdot$ Metabolism $\cdot$ Micropropagation $\cdot$ Plant growth regulators $\cdot$ Plant quality $\cdot$ Somaclonal variation

\section{Introduction}

Lamprocapnos spectabilis (L.) Fukuhara is a plant species of the Fumariaceae botanical family, well-known for its exceptional heart-shaped red, white, or pink flowers. The species is among the most valuable in the floristic market. It has also potential in landscape architecture; in gardens and parks worldwide (Hodges 2012). Moreover, the species is valued in medicine and cosmetology (Iwasa and Kim 1997; McNulty et al. 2007). The development of horticulture allowed to easily force the blooming of bleeding heart any time of the year (Hodges 2012). However, the efficiency of

Dariusz Kulus dkulus@gmail.com

1 Faculty of Agriculture and Biotechnology, Laboratory of Ornamental Plants and Vegetable Crops, UTP University of Science and Technology in Bydgoszcz, 6 Bernardyńska St, 85-029 Bydgoszcz, Poland traditional reproduction via root cuttings is limited by the low number of cuttings produced or unfavorable biotic and abiotic conditions during cultivation. They can negatively affect not only the yield size but also the content of active components found in bleeding heart (mainly isoquinolines) and, thus, the quality of the plant material. Therefore, for commercial production, it is necessary to develop a more effective, tissue-culture-based protocol.

Approximately 200 plant genera (mostly ornamentals) are now produced on a mass scale in commercial laboratories worldwide (Kulus 2015a). Despite they are critical to the species commercial success, there are just a few studies related to tissue culture systems in bleeding heart, related mostly to somatic embryogenesis (Lee and Lee 2003; Lee et al. 2004). Somatic embryogenesis (SE), however, is a complex process facing several bottlenecks reported also with bleeding heart, e.g., asynchronous development of embryos, difficulties with embryo maturation, and conversion into complete plantlets (Kulus 2020a). Moreover, SE 
may not be a genetic stability guarantee if a callus phase is involved, while a suspension culture system is susceptible to contamination development and requires expensive bioreactors (Joshi and Kumar 2013). Consequently, developing a rapid and easy-to-perform clonal micropropagation protocol is also important.

Meristematic explants; such as shoot tips, shoot apices, or nodal segments; produce less variation in vitro than highly differentiated tissues such as roots, leaves, and stems (Krishna et al. 2016). Activation of axillary buds located in the leaf axil can provide a high multiplication ratio in a short time (Grzegorczyk-Karolak et al. 2015). In contrast to SE performed in liquid culture systems, propagation via axillary bud activation is quite easy to perform and the shoots are less prone to hyperhydration occurrence. This is especially important during acclimatization to ex vitro conditions.

Composition of the culture medium is a vital element affecting the efficiency of a micropropagation protocol. Auxins and cytokinins are usually indispensable for the induction of de novo regeneration in plants cultured in vitro (Gaspar et al. 1996). Among several other functions, auxins are usually involved in the induction of embryogenesis, rhizogenesis, and callogenesis, while cytokinins stimulate the proliferation of shoots (Simon and Petrášek 2011; Dobránszki and Mendler-Drienyovszki 2014). Plant hormones, however, rarely work alone and a simultaneous or sequential combination of various PGRs is necessary to achieve a high-scale propagation ratio. The optimal composition of the culture medium depends on the genotype, explant parameters, and desired type of morphogenetic response.

PGRs affect not only the regeneration of plant organs, and their further acclimatization ability, but also the biosynthetic pathway of primary and secondary metabolites, which might be of significant importance to the pharmacological industry (Lucchesini et al. 2009). For example, Grzegorczyk-Karolak et al. $(2015,2016)$ found that the in vitro culture of Scutellaria alpina L. and Scutellaria altissima L. can be an effective system for the overproduction of bioactive compounds with different pharmacological activity during long-term subculturing. In contrast, studies on exploiting the potential of in vitro cultures in producing valuable metabolites in plants of the Fumariaceae family are still underdeveloped.

Another important issue related to plant tissue culture is the so-called somaclonal variation, i.e., genetic and/or phenotype variation induced by in vitro culture conditions. This phenomenon usually occurs in response to a high concentration of PGRs, which induce the formation of callus; a highly unstable quasi-tissue. Somaclonal variation is generally unwanted in the reproduction of elite plant material. It can be useful, though, in breeding programs as reported with chrysanthemum (Miler and Zalewska 2014). Currently, there is no information on the stability of $L$. spectabilis reproduced in vitro. Therefore, analyses of its genetic integrity are important when developing a mass-scale micropropagation protocol.

The aim of this research was to analyze the morphogenetic events in two popular cultivars of Lamprocapnos spectabilis ('Gold Heart' and 'White Gold') micropropagated in culture media with various combinations of PGRs. The stability of the produced plantlets was verified with biochemical and molecular markers. The viability and quality of the ex vitro-transferred plants were also evaluated.

\section{Materials and Methods}

\section{Basal Medium and Physical Conditions in the Growth Chamber}

The Murashige and Skoog (1962) medium (MS) modified by increasing by half the concentration of calcium II chloride $\left(\mathrm{CaCl}_{2} \cdot 6 \mathrm{H}_{2} \mathrm{O}\right)$, iron sulfate $\left(\mathrm{FeSO}_{4}\right)$ and $\mathrm{Na}_{2}$ EDTA $2 \mathrm{H}_{2} \mathrm{O}$, supplemented with $0.09 \mathrm{M}$ sucrose, and solidified with $0.8 \%$ $(w / v)$ agar (Biocorp, Poland) was used in the experiment. The $\mathrm{pH}$ was adjusted to 5.8 (with $0.1 \mathrm{M} \mathrm{HCl}$ and $0.1 \mathrm{M}$ $\mathrm{NaOH}$; Chempur, Poland) after adding all media components (Chemia, Poland), before sterilization at $105 \mathrm{kPa}$ and $121{ }^{\circ} \mathrm{C}$ for $20 \mathrm{~min}$. The medium $(40 \mathrm{~mL})$ was poured into $350-\mathrm{mL}$ vessels and sealed with plastic caps.

The cultures were grown in the growth chamber at $24{ }^{\circ} \mathrm{C} \pm 1{ }^{\circ} \mathrm{C}$, under 16 -h photoperiod conditions and photosynthetic photon flux density (PPFD) of $29.8 \mu \mathrm{mol} \cdot \mathrm{m}^{-2} \cdot \mathrm{s}^{-1}$ provided by standard cool daylight TLD 54/36 W fluorescent tubes with a color temperature of $6200 \mathrm{~K}$ (Koninklijke Philips Electronics N.V., the Netherlands).

\section{Biological Material}

In vitro-derived shoots of Lamprocapnos spectabilis (L.) Fukuhara 'Gold Heart' and 'White Gold' were used as the donor plants. Axenic cultures of the two cultivars were obtained from the in vitro gene bank of the Laboratory of Ornamental Plants and Vegetable Crops, Faculty of Agriculture and Biotechnology, UTP University of Science and Technology, Bydgoszcz, Poland.

To produce the required number of explants, the donor plants were cloned via the single-node method in the modified PGRs-free MS medium (as above) in two propagation cycles, i.e., for about five months.

\section{Effect of Various Combinations of Growth Regulators on the Multiplication and Morphogenetic Response of Explants}

The 10-week-old shoots were cut into nodal segments, 5-10 mm-in-length (Fig. 1a), without leaves and inoculated 
vertically in the modified MS medium; four explants per jar. Indole-3-acetic acid (IAA) or indole-3-butyric acid (IBA) were combined with 6-benzyladenine (BA) or 6-furfurylaminopurine (kinetin, KIN), each at 0.5 or $2.0 \mathrm{mg} \cdot \mathrm{L}^{-1}$. All PGRs were provided by Sigma-Aldrich $®$, USA, a PGRs-free control was also considered. A total of 17 experimental combinations were included (Table 1). The in vitro cultures were cultivated for eight weeks. One jar was considered a single repetition, the experiment was repeated thrice.

\section{Morphological Analysis of Plants and Micropropagation Efficiency Evaluation}

After a single propagation cycle, several morphological parameters were evaluated, including the mean number of shoots and leaves regenerated from a single inoculated explant, as well as the length [mm], fresh (FW) $[\mathrm{mg}]$, and dry weight (DW) [\%] of shoots. The multiplication ratio was assessed by counting the number of secondary explants (nodal segments) that could be easily excised from the recovered shoots. Also, the rooting efficiency [\%], number, and length [mm] of roots were included. Moreover, callus regeneration frequency [\%], its fresh [mg], and dry weight [\%] were estimated. To analyze the dry weight, shoots or calli were desiccated in a laboratory oven at $105^{\circ} \mathrm{C}$ for $180 \mathrm{~min}$.

\section{Biochemical Array}

Spectrophotometric analysis of in vitro-grown plant pigments, extracted from at least five 100-mg-fresh-shoot samples, from every experimental combination was performed. The extraction of chlorophylls and carotenoids was performed with the method described by Lichtenthaler (1987) with $100 \%$ acetone. The spectrophotometric analysis of

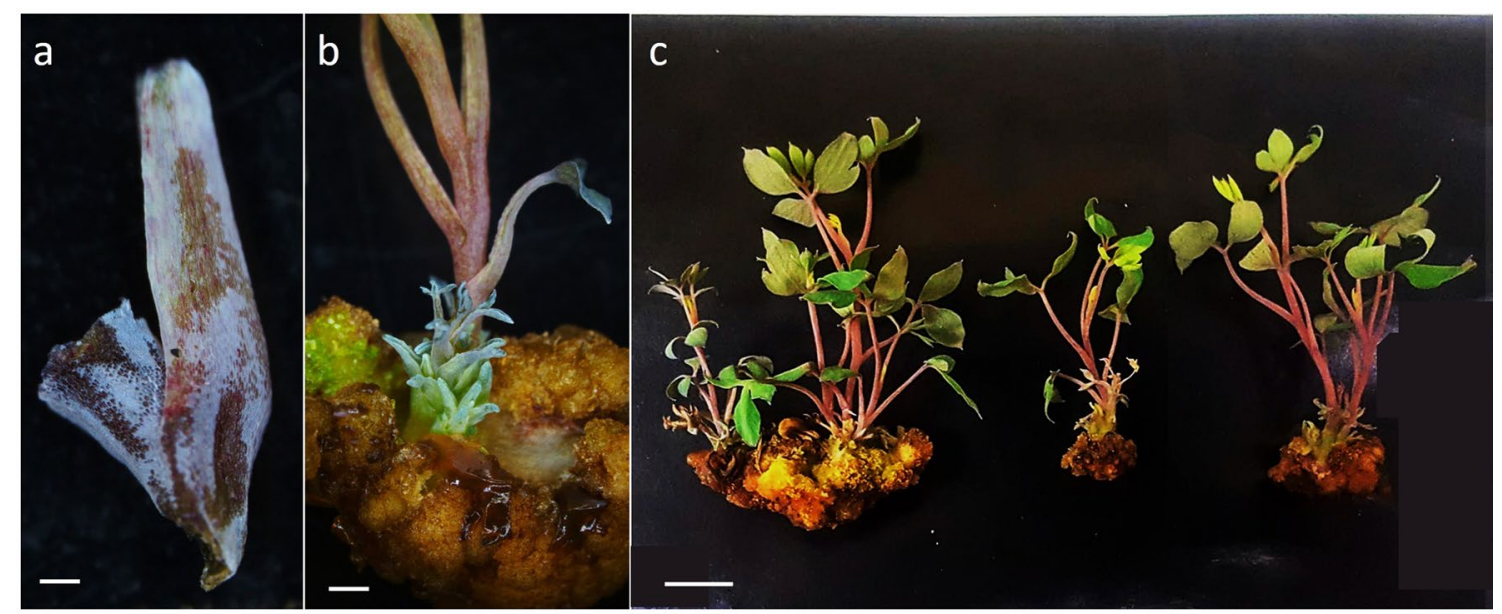

d

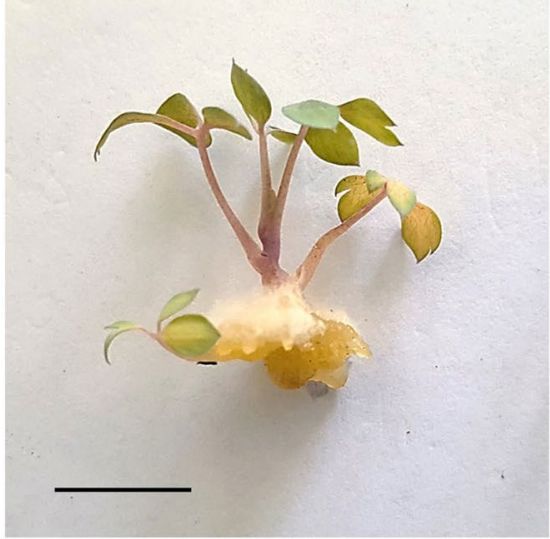

e

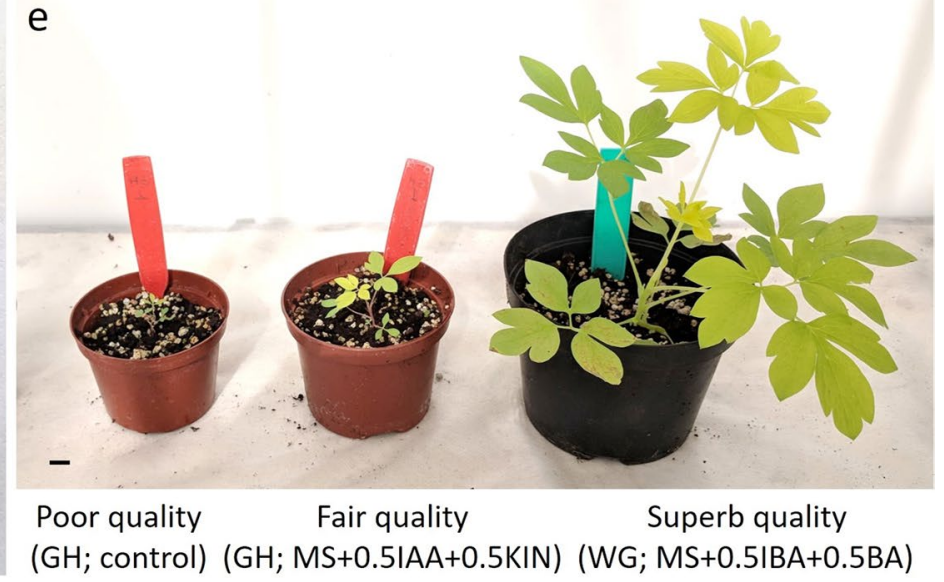

Fig. 1 Micropropagation and acclimatization of Lamprocapnos spectabilis. a single-node explant used in the experiment; b callogenesis and proliferation of axillary shoots in bleeding heart GH cultured in MS medium with $2.0 \mathrm{mg} \cdot \mathrm{L}^{-1} \mathrm{IAA}$ and $0.5 \mathrm{mg} \cdot \mathrm{L}^{-1} \mathrm{BA}$ after 5 weeks of culture; $\mathbf{c}$ fully developed shoots of bleeding heart $\mathrm{GH}$ produced in MS medium with $0.5 \mathrm{mg} \cdot \mathrm{L}^{-1} \mathrm{IAA}$ and $0.5 \mathrm{mg} \cdot \mathrm{L}^{-1} \mathrm{BA}$ after 8 weeks of culture; $\mathbf{d}$ rooted microshoot of bleeding heart $\mathrm{GH}$ prepared for acclimatization after 10 weeks of culture; e bleeding heart plants with different origin and quality after two months of ex vitro growth. $B A$ 6-benzyladenine, $G H$ 'Gold Heart', $I A A$ indole-3-acetic acid, $I B A$ indole-3-butyric acid, KIN kinetin, MS Murashige and Skoog (1962), $W G$ 'White Gold'. bar $=1 \mathrm{~mm}(\mathbf{a}, \mathbf{b})$ or $1 \mathrm{~cm}(\mathbf{c}-\mathbf{e})$ 
Table 1 Influence of culture medium composition on the mean number of shoots and leaves formed from a single-node explant, shoot length $[\mathrm{mm}]$, multiplication ratio, and callus regeneration frequency [\%]

\begin{tabular}{|c|c|c|c|c|c|c|c|c|}
\hline \multicolumn{4}{|c|}{ PGR $*$ concentration $\left[\mathrm{mg} \cdot \mathrm{L}^{-1}\right]$} & \multirow[t]{2}{*}{ Shoot mean number } & \multirow[t]{2}{*}{ Leaf mean number } & \multirow[t]{2}{*}{ Shoot length [mm] } & \multirow[t]{2}{*}{ Multiplication ratio } & \multirow[t]{2}{*}{ Callus $[\%]$} \\
\hline IAA & IBA & BA & KIN & & & & & \\
\hline \multicolumn{9}{|c|}{ Gold Heart } \\
\hline- & - & - & - & $1.9 \pm 0.4 \mathrm{a}^{1}$ & $12.6 \pm 1.9 \mathrm{ab}$ & $24.0 \pm 2.6 \mathrm{a}-\mathrm{d}$ & $5.1 \pm 0.9 \mathrm{ab}$ & $0.0 \mathrm{~d}$ \\
\hline 0.5 & - & 0.5 & - & $1.9 \pm 0.5 \mathrm{a}$ & $15.8 \pm 2.4 \mathrm{a}$ & $26.3 \pm 1.8 \mathrm{a}-\mathrm{c}$ & $5.9 \pm 1.0 \mathrm{a}$ & $100 \mathrm{a}$ \\
\hline 0.5 & - & 2.0 & - & $1.9 \pm 0.4 \mathrm{a}$ & $10.3 \pm 1.5 \mathrm{ab}$ & $14.8 \pm 2.3 \mathrm{c}-\mathrm{e}$ & $4.2 \pm 0.8 \mathrm{ab}$ & $100 \mathrm{a}$ \\
\hline 0.5 & - & - & 0.5 & $1.5 \pm 0.2 \mathrm{a}$ & $8.0 \pm 1.0 \mathrm{~b}$ & $14.0 \pm 1.6 \mathrm{de}$ & $3.1 \pm 0.4 \mathrm{ab}$ & $50.0 \mathrm{bc}$ \\
\hline 0.5 & - & - & 2.0 & $2.0 \pm 0.2 \mathrm{a}$ & $11.8 \pm 1.0 \mathrm{ab}$ & $15.1 \pm 1.1 \mathrm{c}-\mathrm{e}$ & $4.4 \pm 0.5 \mathrm{ab}$ & $87.5 \mathrm{ab}$ \\
\hline 2.0 & - & 0.5 & - & $1.3 \pm 0.2 \mathrm{a}$ & $10.5 \pm 1.9 \mathrm{ab}$ & $28.1 \pm 4.2 \mathrm{a}$ & $4.0 \pm 0.7 \mathrm{ab}$ & $100 \mathrm{a}$ \\
\hline 2.0 & - & 2.0 & - & $2.0 \pm 0.3 \mathrm{a}$ & $11.3 \pm 1.8 \mathrm{ab}$ & $9.6 \pm 1.0 \mathrm{e}$ & $4.3 \pm 0.7 \mathrm{ab}$ & $100 \mathrm{a}$ \\
\hline 2.0 & - & - & 0.5 & $1.3 \pm 0.2 \mathrm{a}$ & $6.3 \pm 0.4 \mathrm{~b}$ & $22.3 \pm 1.2 \mathrm{a}-\mathrm{d}$ & $2.5 \pm 0.3 \mathrm{~b}$ & $0.0 \mathrm{~d}$ \\
\hline 2.0 & - & - & 2.0 & $1.9 \pm 0.4 \mathrm{a}$ & $12.8 \pm 1.4 \mathrm{ab}$ & $16.3 \pm 2.0 \mathrm{~b}-\mathrm{e}$ & $5.0 \pm 0.7 \mathrm{ab}$ & $0.0 \mathrm{~d}$ \\
\hline- & 0.5 & 0.5 & - & $1.6 \pm 0.3 \mathrm{a}$ & $10.7 \pm 2.4 \mathrm{ab}$ & $22.7 \pm 2.2 \mathrm{a}-\mathrm{d}$ & $4.1 \pm 1.0 \mathrm{ab}$ & $100 \mathrm{a}$ \\
\hline- & 0.5 & 2.0 & - & $2.1 \pm 0.3 \mathrm{a}$ & $11.8 \pm 1.5 \mathrm{ab}$ & $14.9 \pm 1.2 \mathrm{c}-\mathrm{e}$ & $4.9 \pm 0.9 \mathrm{ab}$ & $100 \mathrm{a}$ \\
\hline- & 0.5 & - & 0.5 & $1.3 \pm 0.2 \mathrm{a}$ & $6.9 \pm 0.7 \mathrm{~b}$ & $19.9 \pm 1.5 \mathrm{a}-\mathrm{e}$ & $2.8 \pm 0.5 \mathrm{ab}$ & $0.0 \mathrm{~d}$ \\
\hline- & 0.5 & - & 2.0 & $1.1 \pm 0.1 \mathrm{a}$ & $7.5 \pm 1.0 \mathrm{~b}$ & $25.1 \pm 1.4 \mathrm{a}-\mathrm{d}$ & $3.2 \pm 0.4 \mathrm{ab}$ & $12.5 \mathrm{~cd}$ \\
\hline- & 2.0 & 0.5 & - & $1.8 \pm 0.3 \mathrm{a}$ & $11.3 \pm \mathrm{ab}$ & $26.9 \pm 3.1 \mathrm{ab}$ & $4.3 \pm 0.9 \mathrm{ab}$ & $100 \mathrm{a}$ \\
\hline- & 2.0 & 2.0 & - & $1.8 \pm 0.4 \mathrm{a}$ & $6.8 \pm 1.2 b$ & $8.2 \pm 2.1 \mathrm{e}$ & $2.6 \pm 0.3 \mathrm{ab}$ & $100 \mathrm{a}$ \\
\hline- & 2.0 & - & 0.5 & $1.1 \pm 0.1 \mathrm{a}$ & $6.1 \pm 0.7 \mathrm{~b}$ & $26.0 \pm 3.0 \mathrm{a}-\mathrm{c}$ & $2.8 \pm 0.4 \mathrm{ab}$ & $100 \mathrm{a}$ \\
\hline- & 2.0 & - & 2.0 & $2.0 \pm 0.4 \mathrm{a}$ & $10.5 \pm 2.0 \mathrm{ab}$ & $9.8 \pm 3.8 \mathrm{e}$ & $4.8 \pm 1.2 \mathrm{ab}$ & $50.0 \mathrm{bc}$ \\
\hline \multicolumn{9}{|c|}{ White Gold } \\
\hline- & - & - & - & $1.1 \pm 0.1 \mathrm{~b}$ & $8.3 \pm 1.5 b$ & $17.0 \pm 1.5 \mathrm{a}-\mathrm{c}$ & $2.8 \pm 0.5 \mathrm{~b}$ & $0.0 \mathrm{c}$ \\
\hline 0.5 & - & 0.5 & - & $2.6 \pm 0.4 \mathrm{ab}$ & $14.6 \pm 1.9 \mathrm{ab}$ & $17.0 \pm 1.6 \mathrm{a}-\mathrm{c}$ & $6.3 \pm 0.8 \mathrm{ab}$ & $0.0 \mathrm{c}$ \\
\hline 0.5 & - & 2.0 & - & $2.6 \pm 0.3 \mathrm{ab}$ & $8.8 \pm 0.7 \mathrm{~b}$ & $6.4 \pm 0.7 \mathrm{f}$ & $3.6 \pm 0.3 \mathrm{~b}$ & $100 \mathrm{a}$ \\
\hline 0.5 & - & - & 0.5 & $1.4 \pm 0.3 \mathrm{~b}$ & $8.4 \pm 0.5 b$ & $16.0 \pm 1.3 \mathrm{a}-\mathrm{d}$ & $3.3 \pm 0.3 b$ & $0.0 \mathrm{c}$ \\
\hline 0.5 & - & - & 2.0 & $2.0 \pm 0.4 \mathrm{~b}$ & $10.9 \pm 1.4 \mathrm{~b}$ & $13.6 \pm 1.1 \mathrm{c}-\mathrm{e}$ & $5.0 \pm 0.7 \mathrm{~b}$ & $0.0 \mathrm{c}$ \\
\hline 2.0 & - & 0.5 & - & $1.9 \pm 0.3 b$ & $11.6 \pm 1.4 \mathrm{~b}$ & $15.1 \pm 1.2 \mathrm{a}-\mathrm{e}$ & $5.0 \pm 0.7 \mathrm{~b}$ & $0.0 \mathrm{c}$ \\
\hline 2.0 & - & 2.0 & - & $2.0 \pm 0.3 \mathrm{~b}$ & $14.5 \pm 1.3 \mathrm{ab}$ & $10.0 \pm 0.5 \mathrm{~d}-\mathrm{f}$ & $5.3 \pm 0.4 b$ & $100 \mathrm{a}$ \\
\hline 2.0 & - & - & 0.5 & $1.0 \pm 0.0 \mathrm{~b}$ & $7.1 \pm 0.4 \mathrm{~b}$ & $17.0 \pm 0.8 \mathrm{a}-\mathrm{c}$ & $2.6 \pm 0.2 b$ & $0.0 \mathrm{c}$ \\
\hline 2.0 & - & - & 2.0 & $1.9 \pm 0.2 \mathrm{~b}$ & $11.5 \pm 1.9 \mathrm{~b}$ & $14.9 \pm 0.5$ a-e & $4.6 \pm 0.7 \mathrm{~b}$ & $0.0 \mathrm{c}$ \\
\hline- & 0.5 & 0.5 & - & $1.8 \pm 0.2 \mathrm{~b}$ & $12.1 \pm 1.0 \mathrm{~b}$ & $14.6 \pm 1.3 \mathrm{a}-\mathrm{e}$ & $5.3 \pm 0.5 b$ & $100 \mathrm{a}$ \\
\hline- & 0.5 & 2.0 & - & $4.0 \pm 1.0 \mathrm{a}$ & $22.1 \pm 5.1 \mathrm{a}$ & $14.4 \pm 3.4 \mathrm{~b}-\mathrm{e}$ & $9.8 \pm 2.4 \mathrm{a}$ & $100 \mathrm{a}$ \\
\hline- & 0.5 & - & 0.5 & $1.4 \pm 0.2 \mathrm{~b}$ & $8.5 \pm 0.6 \mathrm{~b}$ & $16.8 \pm 1.0 \mathrm{a}-\mathrm{d}$ & $3.0 \pm 0.3 b$ & $0.0 \mathrm{c}$ \\
\hline- & 0.5 & - & 2.0 & $1.3 \pm 0.2 \mathrm{~b}$ & $9.5 \pm 0.8 \mathrm{~b}$ & $19.3 \pm 1.9 \mathrm{a}-\mathrm{c}$ & $3.7 \pm 0.3 b$ & $50.0 \mathrm{~b}$ \\
\hline- & 2.0 & 0.5 & - & $1.7 \pm 0.3 b$ & $10.4 \pm 1.7 \mathrm{~b}$ & $15.9 \pm 1.1 \mathrm{a}-\mathrm{d}$ & $4.1 \pm 0.8 \mathrm{~b}$ & $100 \mathrm{a}$ \\
\hline- & 2.0 & 2.0 & - & $1.3 \pm 0.2 \mathrm{~b}$ & $7.1 \pm 1.0 \mathrm{~b}$ & $8.3 \pm 1.1$ ef & $2.4 \pm 0.3 \mathrm{~b}$ & $100 \mathrm{a}$ \\
\hline- & 2.0 & - & 0.5 & $1.7 \pm 0.3 b$ & $10.7 \pm 2.2 b$ & $21.3 \pm 1.3 \mathrm{ab}$ & $4.5 \pm 0.8 \mathrm{~b}$ & $87.5 \mathrm{a}$ \\
\hline- & 2.0 & - & 2.0 & $1.6 \pm 0.3 b$ & $10.1 \pm 1.3 \mathrm{~b}$ & $21.4 \pm 1.3 \mathrm{a}$ & $4.1 \pm 0.8 \mathrm{~b}$ & $100 \mathrm{a}$ \\
\hline
\end{tabular}

$B A$ 6-benzyladenine, $I A A$ indole-3-acetic acid, IBA indole-3-butyric acid, KIN kinetin, $P G R$ plant growth regulator

${ }^{1}$ Means \pm standard errors in columns marked with the same letter do not differ significantly according to the HSD Tukey's test $(P \leq 0.05)$;

extracts was performed in the spectrophotometer (SmartSpec Plus ${ }^{\mathrm{TM}}$ BioRad, US).

Absorption maxima were defined for pigment-specific wavelengths $\left(\lambda_{\max }\right)$ : for carotenoids at $470 \mathrm{~nm}$, and for chlorophyll $a$ and $b$ at 645 and $662 \mathrm{~nm}$, respectively. The content of chlorophylls and carotenoids per gram of fresh matter of shoots was calculated with the algebraic method following Lichtenthaler and Buschmann (2001).

\section{Genetic Stability Evaluation}

The genetic fidelity of in vitro-propagated $L$. spectabilis 'White Gold' shoots was assessed using randomly 
amplified polymorphic DNA (RAPD) and start codon target polymorphism (SCoT) markers. A total of $68 \mathrm{spec}-$ imens (four from each experimental combination) were included in the analysis. Total genomic DNA was isolated from fresh tissues using a Genomic Mini AX Plant Spin kit (A\&A Biotechnology, Poland), according to the manufacturer's instruction. The isolated DNA was stored at $4{ }^{\circ} \mathrm{C}$.

A total of 20 primers (10 RAPD and 10 SCoT, Genomed, Poland, Table 7) were used for the PCR reaction. PCR was performed in a BioRad C1000 Touch thermal cycler with heated cover (Bio-Rad, USA) in the $25-\mu \mathrm{L}$ reaction solution. The composition of the reaction solution, PCR profiles, and electrophoretic separation of amplified DNA fragments were described earlier in Kulus (2020b; Open Access). Gel images were recorded using a GelDoc XR + Gel Photodocumentation System (Bio-Rad, USA) UV transilluminator with Image Lab 4.1 software. Molecular weights of the fragments were estimated using a 100 - 3,000 bp DNA molecular marker (100 bp DNA Ladder H3 RTU, Nippon Genetics Europe GmbH, Germany).

The banding patterns were recorded as $0-1$ binary matrices, where " 1 " indicates the presence and " 0 " the absence of a given fragment followed by statistical analysis. For every primer tested the total number of bands, monomorphic, polymorphic (present in the electrophoretic profile of more than one individual) and specific/ unique loci (present in the electrophoretic profile of a single individual) was counted.

\section{In Vitro Rooting and Acclimatization to Ex Vitro Conditions}

Five shoots from each experimental combination were rooted and acclimatized. For this purpose, the 'Gold Heart' and 'White Gold' shoots were dissected and transferred on the rooting MS medium containing half-strength macronutrients $(1 / 2 \mathrm{MS}), 2 \%$ sucrose, and $1.0 \mathrm{mg} \cdot \mathrm{L}^{-1}$ 1-naphthaleneacetic acid (NAA) for 14 days.

Acclimatization was conducted from July 15 to July 29 in natural light conditions in a glasshouse at the temperature $19.5-27.3{ }^{\circ} \mathrm{C}$ (mean $23.1^{\circ} \mathrm{C}$ ) and $59-76 \%$ relative humidity (mean 66.7\%). Bleeding hearts were grown in plastic trays filled with a mixture of peat and perlite $(2: 1)$, sprayed with water, and covered with perforated foil and geo-cover. The acclimatization effectiveness, i.e., survival rate [\%] and quality of plants, was assessed after 14 days. Plants that remained in the unchanged healthy form were considered fair quality. Those, which survived acclimatization but were tiny or had withered leaves after two weeks were considered poor quality. The quality of shoots with evident signs of growth, i.e., development of new healthy leaves, was considered superb. After one month, the plants were transferred to individual plastic pots filled with the same substrate and planted in a permanent place on benches.

\section{Statistical Analysis}

The single-factor experiment was performed in a completely randomized design. The Freeman-Tukey transformation was used for the data expressed as a percentage. The results were statistically analyzed with one-way analysis of variance (ANOVA), and the comparisons of means were made with HSD Tukey's Multiple Comparison Test $(P \leq 0.05)$ using Statistica 12.0 and ANALWAR-5.2-FR tools. Tables with results provide real numerical data, while alphabet letters point to homogenous groups, following the statistical calculations based on transformed data.

Associations between the analyzed traits of plants were analyzed, based on the Pearson correlation coefficient ( $r$; $P \leq 0.05)$. The associations were considered as moderate $(0.3<|r| \leq 0.5)$, strong $(0.5<|r| \leq 0.7)$ or very strong $(0.7<1$ $r \mid \leq 1.0)$. Low correlations $(|\mathrm{r}| \leq 0.3)$ were not included.

As for the molecular analysis, Agglomerative Hierarchical Clustering with Unweighted Pair-Group Average Method (AHC UPGMA) was used to draw the dendrograms. GeneAlEx 6.5 software (Peakall and Smouse 2012) was used to perform the principal component analysis (PCoA). Population groups were distinguished based on the analysis of molecular variance (AMOVA) estimates.

\section{Results}

\section{Effect of PGRs Combinations on the Multiplication and Morphogenetic Response of Explants}

The effect of plant growth regulators on the morphogenetic response of explants was cultivar-specific (Table 1). Caulogensis was evident in the third week of the in vitro culture. There was no influence of culture medium composition on the number of shoots produced by a 'Gold Heart' explant $(1.1-2.1)$. The number of leaves developed by a single explant in this cultivar varied from 6.1 (MS with $2.0 \mathrm{mg} \cdot \mathrm{L}^{-1}$ IBA and $0.5 \mathrm{mg} \cdot \mathrm{L}^{-1} \mathrm{KIN}$ ) to 15.8 (MS with $0.5 \mathrm{mg} \cdot \mathrm{L}^{-1} \mathrm{IAA}$ and $0.5 \mathrm{mg} \cdot \mathrm{L}^{-1} \mathrm{BA}$ ). The longest shoots were produced on the MS medium with $2.0 \mathrm{mg} \cdot \mathrm{L}^{-1}$ IAA and $0.5 \mathrm{mg} \cdot \mathrm{L}^{-1}$ BA $(28.1 \mathrm{~mm})$. None of the PGRs combinations, however, improved the parameters of shoots compared to the PGRsfree control. The highest number of offspring explants produced from a single inoculated nodal segment (5.9) was dissected after applying the medium with $0.5 \mathrm{mg} \cdot \mathrm{L}^{-1} \mathrm{IAA}$ and $0.5 \mathrm{mg} \cdot \mathrm{L}^{-1} \mathrm{BA}$. Most of the 'Gold Heart' explants 
$(50.0-100 \%)$ formed callus at the base of shoots (Fig. 1bc), except for those cultured on the control medium and in the presence of $2.0 \mathrm{mg} \cdot \mathrm{L}^{-1} \mathrm{IAA}$ and 0.5 or $2.0 \mathrm{mg} \cdot \mathrm{L}^{-1} \mathrm{KIN}$ or $0.5 \mathrm{mg} \cdot \mathrm{L}^{-1}$ IBA and 0.5 or $2.0 \mathrm{mg} \cdot \mathrm{L}^{-1} \mathrm{KIN}$ (Table 1 ).

As for the 'White Gold' cultivar, the highest number of shoots regenerated by a single inoculated explant (4.0) was found on the MS medium with $0.5 \mathrm{mg} \cdot \mathrm{L}^{-1} \mathrm{IBA}$ and $2.0 \mathrm{mg} \cdot \mathrm{L}^{-1} \mathrm{BA}$, and it was nearly fourfold higher than in the control medium devoid of auxins and cytokinins (Table 1). This PGRs combination also increased the number of leaves produced (22.1) compared to most other treatments $(7.1-12.1)$, and the multiplication ratio (9.8). The longest shoots (over $21 \mathrm{~mm}$ ) were found in the medium with $2.0 \mathrm{mg} \cdot \mathrm{L}^{-1}$ IBA and 0.5 or $2.0 \mathrm{mg} \cdot \mathrm{L}^{-1}$ $\mathrm{KIN}$, although they were not statistically different from the control shoots $(17.0 \mathrm{~mm})$. On the other hand, media with $0.5 \mathrm{mg} \cdot \mathrm{L}^{-1} \mathrm{IAA}$ and $2.0 \mathrm{mg} \cdot \mathrm{L}^{-1} \mathrm{BA}$, as well as $2.0 \mathrm{mg} \cdot \mathrm{L}^{-1} \mathrm{IBA}$ and $2.0 \mathrm{mg} \cdot \mathrm{L}^{-1} \mathrm{BA}$ suppressed the elongation of shoots (Table 1). No callogenesis was reported in the control medium, but also in several other combinations containing auxins (mainly IAA) and cytokinins (Table 1).

In L. spectabilis 'Gold Heart', the highest fresh weight of shoots was reported in the medium with $2.0 \mathrm{mg} \cdot \mathrm{L}^{-1}$ IBA and $2.0 \mathrm{mg} \cdot \mathrm{L}^{-1} \mathrm{KIN}(249.1 \mathrm{mg})$, although it was not statistically different from the shoots grown on the PGRsfree control (144.6 mg). Application of media fortified with $2.0 \mathrm{mg} \cdot \mathrm{L}^{-1} \mathrm{IAA}$ and $2.0 \mathrm{mg} \cdot \mathrm{L}^{-1} \mathrm{BA}, 2.0 \mathrm{mg} \cdot \mathrm{L}^{-1}$ IBA and $2.0 \mathrm{mg} \cdot \mathrm{L}^{-1} \mathrm{BA}$, as well as $2.0 \mathrm{mg} \cdot \mathrm{L}^{-1} \mathrm{IBA}$ and $2.0 \mathrm{mg} \cdot \mathrm{L}^{-1} \mathrm{KIN}$ led to a significant decrease in the share of dry weight in shoots $(4.6-7.1 \%)$, compared to the other treatments $(15.5-21.5 \%)$. On the other hand, the highest fresh weight of callus was found in the experimental combinations with $2.0 \mathrm{mg} \cdot \mathrm{L}^{-1}$ IBA and 0.5 or $2.0 \mathrm{mg} \cdot \mathrm{L}^{-1}$ BA $(336.2-394.9 \mathrm{mg})$. Only the medium with $2.0 \mathrm{mg} \cdot \mathrm{L}^{-1}$ IAA and $0.5 \mathrm{mg} \cdot \mathrm{L}^{-1} \mathrm{BA}$ led to a significant decline in the share of DW in the fresh callus mass (7.8\%) (Table 2).

As for bleeding heart 'White Gold', the highest FW in shoots were reported after using the medium fortified with $0.5 \mathrm{mg} \cdot \mathrm{L}^{-1}$ IAA and $0.5 \mathrm{mg} \cdot \mathrm{L}^{-1} \mathrm{BA}$ or $0.5 \mathrm{mg} \cdot \mathrm{L}^{-1}$ IBA and $2.0 \mathrm{mg} \cdot \mathrm{L}^{-1} \mathrm{BA}(336.2-352.0 \mathrm{mg})$. On the other hand, the highest and lowest share of DW in the fresh shoot weight was found in the media with $0.5 \mathrm{mg} \cdot \mathrm{L}^{-1} \mathrm{IBA}$ and $2.0 \mathrm{mg} \cdot \mathrm{L}^{-1} \mathrm{KIN}(29.0 \%)$ and $2.0 \mathrm{mg} \cdot \mathrm{L}^{-1} \mathrm{IBA}$ and $0.5 \mathrm{mg} \cdot \mathrm{L}^{-1} \mathrm{BA}(7.7 \%)$, respectively. MS medium fortified with $0.5 \mathrm{mg} \cdot \mathrm{L}^{-1} \mathrm{IBA}$ and $2.0 \mathrm{mg} \cdot \mathrm{L}^{-1} \mathrm{BA}$ stimulated the most intensive callus formation $(427.6 \mathrm{mg} \mathrm{FW}$ per inoculated explant). Nonetheless, there was no influence of culture medium composition on the share of DW in the fresh callus mass $13.6-23.5 \%$ ) (Table 2).

The highest rooting efficiency in the 'Gold Heart' cultivar was reported with $0.5 \mathrm{mg} \cdot \mathrm{L}^{-1} \mathrm{IAA}$ and $0.5 \mathrm{mg} \cdot \mathrm{L}^{-1}$ KIN (62.5\% rooting rate). Also, $37.5 \%$ shoots grown in the control medium regenerated roots (Table 3 ). The other experimental combinations were less effective in stimulating rhizogenesis $(0.0-14.3 \%$ rooting rate). The highest number of roots produced by a single rooted explant (3.0 -4.0) was reported in the media supplemented with 0.5 or $2.0 \mathrm{mg} \cdot \mathrm{L}^{-1} \mathrm{IBA}$ and $0.5 \mathrm{mg} \cdot \mathrm{L}^{-1} \mathrm{KIN}$. Explants cultured in those two media and in the PGRs-free control regenerated the longest roots $(48.0-64.0 \mathrm{~mm})$ (Table 3$)$.

The MS medium fortified with $0.5 \mathrm{mg} \cdot \mathrm{L}^{-1} \mathrm{IBA}$ and $0.5 \mathrm{mg} \cdot \mathrm{L}^{-1} \mathrm{KIN}$ was superior in terms of root development in the 'White Gold' cultivar (Table 3). This combination stimulated rhizogenesis in $37.5 \%$ explants, with 2.3 roots per explant and the greatest elongation of roots $(35.3 \mathrm{~mm})$. Also, the medium with $2.0 \mathrm{mg} \cdot \mathrm{L}^{-1} \mathrm{IAA}$ and $2.0 \mathrm{mg} \cdot \mathrm{L}^{-1} \mathrm{KIN}$ provided good rooting parameters in this cultivar. Application of $2.0 \mathrm{mg} \cdot \mathrm{L}^{-1} \mathrm{IBA}$ and $0.5 \mathrm{mg} \cdot \mathrm{L}^{-1} \mathrm{KIN}$ resulted in the highest rooting rate $(42.9 \%)$, but the produced roots were shorter $(9.2 \mathrm{~mm})$ than from the previously described media (Table 3).

\section{Effect of Auxins and Cytokinins on the Biosynthesis of Pigments in Shoots of Bleeding Heart}

Medium composition had a significant influence on the biosynthesis of pigments in L. spectabilis (Table 4). The concentration of chlorophyll $a$ in the shoots of bleeding heart 'Gold Heart' was markedly reduced by the experimental combination containing $2.0 \mathrm{mg} \cdot \mathrm{L}^{-1}$ IBA and $2.0 \mathrm{mg} \cdot \mathrm{L}^{-1}$ $\mathrm{KIN}\left(0.08 \mathrm{mg} \cdot \mathrm{g}^{-1}\right.$ fresh tissue). The highest concentration of chlorophyll $b$ was found in the shoots grown in the medium with $0.5 \mathrm{mg} \cdot \mathrm{L}^{-1} \mathrm{IAA}$ and $2.0 \mathrm{mg} \cdot \mathrm{L}^{-1} \mathrm{KIN}\left(0.26 \mathrm{mg} \cdot \mathrm{g}^{-1}\right)$, while the lowest in $0.5 \mathrm{mg} \cdot \mathrm{L}^{-1}$ IAA and $2.0 \mathrm{mg} \cdot \mathrm{L}^{-1} \mathrm{BA}$ $\left(0.08 \mathrm{mg} \cdot \mathrm{g}^{-1}\right)$. The ratio of chlorophyll $a: b$ usually had a value $>1.0$. Only in the shoots of bleeding heart 'Gold Heart' grown in the presence of $2.0 \mathrm{mg} \cdot \mathrm{L}^{-1} \mathrm{IBA}$ and $2.0 \mathrm{mg} \cdot \mathrm{L}^{-1}$ $\mathrm{KIN}$, the concentration of chlorophyll $b\left(0.12 \mathrm{mg} \cdot \mathrm{g}^{-1}\right)$ was higher than of chlorophyll $a\left(0.08 \mathrm{mg} \cdot \mathrm{g}^{-1}\right)$. This medium composition also negatively affected the biosynthesis of carotenoids $\left(0.014 \mathrm{mg} \cdot \mathrm{g}^{-1}\right)$ compared to most other treatments $\left(0.065-0.113 \mathrm{mg} \cdot \mathrm{g}^{-1}\right)$. Some PGR combinations enhanced the production of the analyzed compounds in the 'Gold Heart' cultivar; by even 46.7\% (chlorophyll $a$ ), $73.3 \%$ (chlorophyll $b$ ), or $47.1 \%$ (carotenoids); compared to the control. Those differences, however, were statistically non-significant according to the HSD Tukey's test (Table 4).

Application of MS medium containing 0.5 or $2.0 \mathrm{mg} \cdot \mathrm{L}^{-1}$ IAA and $2.0 \mathrm{mg} \cdot \mathrm{L}^{-1} \mathrm{BA}$ contributed to a decrease in the content of chlorophyll $a$, the ratio of chlorophyll $a$ : $b$, and concentration of carotenoids in the shoots of bleeding heart 'White Gold' (Table 4). On the other hand, the highest and lowest concentration of chlorophyll $b$ was found when using media with $0.5 \mathrm{mg} \cdot \mathrm{L}^{-1}$ IAA and $0.5 \mathrm{mg} \cdot \mathrm{L}^{-1}$ KIN $\left(0.21 \mathrm{mg} \cdot \mathrm{g}^{-1}\right.$ fresh tissue $)$ and $0.5 \mathrm{mg} \cdot \mathrm{L}^{-1}$ IAA and $0.5 \mathrm{mg} \cdot \mathrm{L}^{-1}$ BA $\left(0.11 \mathrm{mg} \cdot \mathrm{g}^{-1}\right)$, respectively. Similarly to 
Table 2 Influence of culture medium composition on the fresh (FW) and dry weight (DW) [mg and \%, respectively] in shoots and calli obtained from a single inoculated explant of Lamprocapnos spectabilis

\begin{tabular}{|c|c|c|c|c|c|c|c|}
\hline \multicolumn{4}{|c|}{ PGR* concentration $\left[\mathrm{mg} \cdot \mathrm{L}^{-1}\right]$} & \multirow[t]{2}{*}{ Shoot FW [mg] } & \multirow{2}{*}{$\begin{array}{l}\text { Share of DW in } \\
\text { shoot [\%] }\end{array}$} & \multirow[t]{2}{*}{ Callus FW [mg] } & \multirow{2}{*}{$\begin{array}{l}\text { Share of DW } \\
\text { in callus [\%] }\end{array}$} \\
\hline IAA & IBA & BA & KIN & & & & \\
\hline \multicolumn{8}{|c|}{ Gold Heart } \\
\hline- & - & - & - & $144.6 \pm 24.3 \mathrm{ab}$ & $20.1 \mathrm{a}$ & $0.0 \mathrm{~g}$ & - \\
\hline 0.5 & - & 0.5 & - & $96.5 \pm 20.3 b$ & $9.1 \mathrm{ab}$ & $104.4 \pm 24.6 \mathrm{df}$ & $10.6 \mathrm{ab}$ \\
\hline 0.5 & - & 2.0 & - & $44.9 \pm 6.5 b$ & $16.0 \mathrm{a}$ & $219.7 \pm 53.2$ b-d & $17.9 \mathrm{ab}$ \\
\hline 0.5 & - & - & 0.5 & $63.6 \pm 10.8 b$ & $18.4 \mathrm{a}$ & $10.5 \pm 5.5 \mathrm{fg}$ & $21.0 \mathrm{ab}$ \\
\hline 0.5 & - & - & 2.0 & $60.7 \pm 15.1 \mathrm{~b}$ & $15.5 \mathrm{a}$ & $18.5 \pm 3.5$ ef & $17.3 \mathrm{ab}$ \\
\hline 2.0 & - & 0.5 & - & $78.7 \pm 17.0 \mathrm{~b}$ & $18.8 \mathrm{a}$ & $75.8 \pm 25.8$ ef & $7.8 \mathrm{~b}$ \\
\hline 2.0 & - & 2.0 & - & $33.7 \pm 7.1 \mathrm{~b}$ & $7.1 \mathrm{~b}$ & $241.0 \pm 41.9$ b-d & $12.4 \mathrm{ab}$ \\
\hline 2.0 & - & - & 0.5 & $92.5 \pm 10.8 b$ & $21.4 \mathrm{a}$ & $0.0 \mathrm{~g}$ & - \\
\hline 2.0 & - & - & 2.0 & $106.9 \pm 28.1 \mathrm{~b}$ & $21.5 \mathrm{a}$ & $0.0 \mathrm{~g}$ & - \\
\hline- & 0.5 & 0.5 & - & $71.0 \pm 15.3 \mathrm{~b}$ & $19.4 \mathrm{a}$ & $150.5 \pm 22.9 \mathrm{c}-\mathrm{e}$ & $16.9 \mathrm{ab}$ \\
\hline- & 0.5 & 2.0 & - & $57.5 \pm 19.5 b$ & $15.5 \mathrm{a}$ & $271.1 \pm 46.3 \mathrm{a}-\mathrm{c}$ & $16.7 \mathrm{ab}$ \\
\hline- & 0.5 & - & 0.5 & $98.9 \pm 10.7 b$ & $19.3 \mathrm{a}$ & $0.0 \mathrm{~g}$ & - \\
\hline- & 0.5 & - & 2.0 & $118.7 \pm 9.2 \mathrm{~b}$ & $17.5 \mathrm{a}$ & $8.6 \pm 4.3 \mathrm{fg}$ & $11.6 \mathrm{ab}$ \\
\hline- & 2.0 & 0.5 & - & $116.1 \pm 22.2 b$ & $18.9 \mathrm{a}$ & $394.9 \pm 39.0 \mathrm{a}$ & $20.9 \mathrm{ab}$ \\
\hline- & 2.0 & 2.0 & - & $28.5 \pm 6.0 \mathrm{~b}$ & $4.6 \mathrm{~b}$ & $336.2 \pm 42.5 \mathrm{ab}$ & $15.9 \mathrm{ab}$ \\
\hline- & 2.0 & - & 0.5 & $73.3 \pm 15.8 b$ & $16.2 \mathrm{a}$ & $114.7 \pm 11.0 \mathrm{~d}-\mathrm{f}$ & $12.0 \mathrm{ab}$ \\
\hline- & 2.0 & - & 2.0 & $249.1 \pm 69.7 \mathrm{a}$ & $5.5 \mathrm{~b}$ & $63.0 \pm 31.4$ ef & $39.4 \mathrm{a}$ \\
\hline \multicolumn{8}{|c|}{ White Gold } \\
\hline- & - & - & - & $49.8 \pm 6.3 \mathrm{ab}$ & $23.3 \mathrm{ab}$ & $0.0 \mathrm{e}$ & - \\
\hline 0.5 & - & 0.5 & - & $352.0 \pm 101.1 \mathrm{a}$ & $12.2 \mathrm{ab}$ & $0.0 \mathrm{e}$ & - \\
\hline 0.5 & - & 2.0 & - & $55.7 \pm 10.5 \mathrm{ab}$ & $9.0 \mathrm{ab}$ & $280.0 \pm 44.9 \mathrm{ab}$ & $16.5 \mathrm{a}$ \\
\hline 0.5 & - & - & 0.5 & $71.5 \pm 6.7 \mathrm{ab}$ & $18.2 \mathrm{ab}$ & $0.0 \mathrm{e}$ & - \\
\hline 0.5 & - & - & 2.0 & $73.6 \pm 8.7 \mathrm{ab}$ & $24.7 \mathrm{ab}$ & $0.0 \mathrm{e}$ & - \\
\hline 2.0 & - & 0.5 & - & $95.7 \pm 17.7 \mathrm{ab}$ & $18.9 \mathrm{ab}$ & $0.0 \mathrm{e}$ & - \\
\hline 2.0 & - & 2.0 & - & $80.5 \pm 11.8 \mathrm{ab}$ & $13.3 \mathrm{ab}$ & $189.9 \pm 32.8 \mathrm{bc}$ & $13.6 \mathrm{a}$ \\
\hline 2.0 & - & - & 0.5 & $66.8 \pm 5.3 \mathrm{ab}$ & $22.6 \mathrm{ab}$ & $0.0 \mathrm{e}$ & - \\
\hline 2.0 & - & - & 2.0 & $94.6 \pm 14.3 \mathrm{ab}$ & $23.4 \mathrm{ab}$ & $0.0 \mathrm{e}$ & - \\
\hline- & 0.5 & 0.5 & - & $49.2 \pm 4.4 \mathrm{ab}$ & $13.8 \mathrm{ab}$ & $117.5 \pm 20.3 b-d$ & $19.7 \mathrm{a}$ \\
\hline- & 0.5 & 2.0 & - & $336.2 \pm 163.4 \mathrm{a}$ & $20.1 \mathrm{ab}$ & $427.6 \pm 128.5 \mathrm{a}$ & $15.2 \mathrm{a}$ \\
\hline- & 0.5 & - & 0.5 & $92.0 \pm 5.4 \mathrm{ab}$ & $17.6 \mathrm{ab}$ & $0.0 \mathrm{e}$ & - \\
\hline- & 0.5 & - & 2.0 & $78.9 \pm 19.5 \mathrm{ab}$ & $29.0 \mathrm{a}$ & $67.7 \pm 22.2 \mathrm{~cd}$ & $12.1 \mathrm{a}$ \\
\hline- & 2.0 & 0.5 & - & $46.8 \pm 10.1 \mathrm{ab}$ & $7.7 \mathrm{~b}$ & $115.6 \pm 14.7$ b-d & $15.0 \mathrm{a}$ \\
\hline- & 2.0 & 2.0 & - & $26.8 \pm 5.2 \mathrm{~b}$ & $9.3 \mathrm{ab}$ & $173.5 \pm 34.1 \mathrm{~b}-\mathrm{d}$ & $19.8 \mathrm{a}$ \\
\hline- & 2.0 & - & 0.5 & $66.0 \pm 11.7 \mathrm{ab}$ & $19.7 \mathrm{ab}$ & $180.3 \pm 21.0 \mathrm{~b}-\mathrm{d}$ & $16.7 \mathrm{a}$ \\
\hline- & 2.0 & - & 2.0 & $86.1 \pm 10.0 \mathrm{ab}$ & $25.7 \mathrm{ab}$ & $139.2 \pm 30.7 \mathrm{~b}-\mathrm{d}$ & $23.5 \mathrm{a}$ \\
\hline
\end{tabular}

${ }^{1}$ Means \pm standard errors in columns marked with the same letter do not differ significantly according to the HSD Tukey's test $(P \leq 0.05)$

* $B A$ 6-benzyladenine, IAA indole-3-acetic acid, $I B A$ indole-3-butyric acid, KIN kinetin, $P G R$ plant growth regulator

'Gold Heart', also in the 'White Gold' cultivar, shoots grown in some PGRs-fortified media had a slightly higher content of metabolites than the control ones. For example, shoots cultured in the medium with $0.5 \mathrm{mg} \cdot \mathrm{L}^{-1} \mathrm{IAA}$ and $0.5 \mathrm{mg} \cdot \mathrm{L}^{-1} \mathrm{KIN}$ produced $46.2 \%$ more chlorophyll $a, 50 \%$ more chlorophyll $b$, and $36.4 \%$ more carotenoids. This tendency, however, was not significant according to Tukey's test (Table 4).
It was also found that explants cultured on the media supplemented with auxins and cytokinins secreted abundantly phenols, resulting in the browning of media already in the first month of in vitro culture. This phenomenon was not observed with the control medium. 
Table 3 Influence of culture medium composition on the rhizogenesis efficiency [\%], number, and length [mm] of roots per rooted explant

\begin{tabular}{|c|c|c|c|c|c|c|}
\hline \multicolumn{4}{|c|}{ PGR $*$ concentration $\left[\mathrm{mg} \cdot \mathrm{L}^{-1}\right]$} & \multirow[t]{2}{*}{ Rooting [\%] } & \multirow{2}{*}{$\begin{array}{l}\text { No. of roots per rooted } \\
\text { explant }\end{array}$} & \multirow[t]{2}{*}{ Root length $[\mathrm{mm}]$} \\
\hline IAA & IBA & BA & KIN & & & \\
\hline \multicolumn{7}{|c|}{ Gold Heart } \\
\hline- & - & - & - & $37.5 a b^{1}$ & $2.0 \pm 0.6 \mathrm{bc}$ & $64.0 \pm 26.2 \mathrm{a}$ \\
\hline 0.5 & - & 0.5 & - & $0.0 \mathrm{~b}$ & - & - \\
\hline 0.5 & - & 2.0 & - & $0.0 \mathrm{~b}$ & - & - \\
\hline 0.5 & - & - & 0.5 & $62.5 \mathrm{a}$ & $1.2 \pm 0.3 \mathrm{c}$ & $22.0 \pm 2.5 \mathrm{bc}$ \\
\hline 0.5 & - & - & 2.0 & $0.0 \mathrm{~b}$ & - & - \\
\hline 2.0 & - & 0.5 & - & $0.0 \mathrm{~b}$ & - & - \\
\hline 2.0 & - & 2.0 & - & $0.0 \mathrm{~b}$ & - & - \\
\hline 2.0 & - & - & 0.5 & $0.0 \mathrm{~b}$ & - & - \\
\hline 2.0 & - & - & 2.0 & $0.0 \mathrm{~b}$ & - & - \\
\hline- & 0.5 & 0.5 & - & $0.0 \mathrm{~b}$ & - & - \\
\hline- & 0.5 & 2.0 & - & $12.5 \mathrm{~b}$ & $1.0 \pm 0.0 \mathrm{c}$ & $8.0 \pm 0.0 \mathrm{c}$ \\
\hline- & 0.5 & - & 0.5 & $12.5 \mathrm{~b}$ & $4.0 \pm 0.0 \mathrm{a}$ & $48.0 \pm 4.0 \mathrm{a}-\mathrm{c}$ \\
\hline- & 0.5 & - & 2.0 & $0.0 \mathrm{~b}$ & - & - \\
\hline- & 2.0 & 0.5 & - & $14.3 \mathrm{~b}$ & $2.0 \pm 0.0 \mathrm{bc}$ & $21.0 \pm 1.0 \mathrm{bc}$ \\
\hline- & 2.0 & 2.0 & - & $0.0 \mathrm{~b}$ & - & - \\
\hline- & 2.0 & - & 0.5 & $12.5 \mathrm{~b}$ & $3.0 \pm 0.0 \mathrm{ab}$ & $60.0 \pm 0.0 \mathrm{ab}$ \\
\hline- & 2.0 & - & 2.0 & $0.0 \mathrm{~b}$ & - & - \\
\hline \multicolumn{7}{|c|}{ White Gold } \\
\hline- & - & - & - & $0.0 \mathrm{c}$ & - & - \\
\hline 0.5 & - & 0.5 & - & $0.0 \mathrm{c}$ & - & - \\
\hline 0.5 & - & 2.0 & - & $0.0 \mathrm{c}$ & - & - \\
\hline 0.5 & - & - & 0.5 & $12.5 \mathrm{bc}$ & $1.0 \pm 0.0 \mathrm{~b}$ & $3.0 \pm 0.0 \mathrm{~b}$ \\
\hline 0.5 & - & - & 2.0 & $12.5 \mathrm{bc}$ & $1.0 \pm 0.0 \mathrm{~b}$ & $5.0 \pm 0.0 \mathrm{~b}$ \\
\hline 2.0 & - & 0.5 & - & $0.0 \mathrm{c}$ & - & - \\
\hline 2.0 & - & 2.0 & - & $0.0 \mathrm{c}$ & - & - \\
\hline 2.0 & - & - & 0.5 & $0.0 \mathrm{c}$ & - & - \\
\hline 2.0 & - & - & 2.0 & $25.0 \mathrm{a}-\mathrm{c}$ & $3.5 \pm 0.5 \mathrm{a}$ & $19.5 \pm 10.5 a b$ \\
\hline- & 0.5 & 0.5 & - & $0.0 \mathrm{c}$ & - & - \\
\hline- & 0.5 & 2.0 & - & $0.0 \mathrm{c}$ & - & - \\
\hline- & 0.5 & - & 0.5 & $37.5 \mathrm{ab}$ & $2.3 \pm 0.9 \mathrm{ab}$ & $35.3 \pm 9.0 \mathrm{a}$ \\
\hline- & 0.5 & - & 2.0 & $0.0 \mathrm{c}$ & - & - \\
\hline- & 2.0 & 0.5 & - & $0.0 \mathrm{c}$ & - & - \\
\hline- & 2.0 & 2.0 & - & $0.0 \mathrm{c}$ & - & - \\
\hline- & 2.0 & - & 0.5 & $42.9 \mathrm{a}$ & $1.5 \pm 0.3 b$ & $9.2 \pm 1.5 \mathrm{~b}$ \\
\hline- & 2.0 & - & 2.0 & $0.0 \mathrm{c}$ & - & - \\
\hline
\end{tabular}

${ }^{1}$ Means \pm standard errors in columns marked with the same letter do not differ significantly according to the HSD Tukey's test $(P \leq 0.05)$

*BA 6-benzyladenine, IAA indole-3-acetic acid, IBA indole-3-butyric acid, KIN kinetin, $P G R$ - plant growth regulator

\section{In Vitro Rooting and Ex Vitro Acclimatization Efficiency}

Shoots produced typical roots with root hair after 18 days of culture on the rooting medium with NAA (Fig. 1d). Nonetheless, the acclimatization efficiency reached from 0.0 to $100 \%$, depending on the cultivar and the composition of the medium used during the multiplication stage (Table 5). Plants, which did not survive the ex vitro transfer died between the fifth and seventh days of cultivation. The survival rate of 'White Gold' plantlets was generally slightly higher than of 'Gold Heart' (64.7 and $50.0 \%$, respectively). The acclimatization efficiency of control 'Gold Heart' microshoots (cultured on the hormone-free medium) was significantly lower (20\%) compared to those produced in some PGRs-supplemented media (Table 5). As for 'White Gold', the highest survival rate $(100 \%)$ was found after previous multiplication in 
Table 4 Influence of culture medium composition on the concentration $\left[\mathrm{mg} \cdot \mathrm{g}^{-1}\right.$ fresh weight] of chlorophyll $a$, chlorophyll $b$, their ratio, and content of total carotenoids in shoots of in vitro-grown $L$. spectabilis

\begin{tabular}{|c|c|c|c|c|c|c|c|}
\hline \multicolumn{4}{|c|}{ PGR $*$ concentration $\left[\mathrm{mg} \cdot \mathrm{L}^{-1}\right]$} & \multirow[t]{2}{*}{ Chlorophyll $a\left[\mathrm{mg} \cdot \mathrm{g}^{-1}\right]$} & \multirow[t]{2}{*}{ Chlorophyll $b\left[\mathrm{mg} \cdot \mathrm{g}^{-1}\right]$} & \multirow[t]{2}{*}{ Chlorophyll $a: b$ ratio } & \multirow[t]{2}{*}{ Carotenoids $\left[\mathrm{mg} \cdot \mathrm{g}^{-1}\right]$} \\
\hline IAA & IBA & BA & KIN & & & & \\
\hline \multicolumn{8}{|c|}{ Gold Heart } \\
\hline- & - & - & - & $0.30 \pm 0.06 \mathrm{ab}$ & $0.15 \pm 0.05$ a-d & $2.25 \pm 0.30 \mathrm{ab}$ & $0.076 \pm 0.008 \mathrm{ab}$ \\
\hline 0.5 & - & 0.5 & - & $0.44 \pm 0.04 \mathrm{a}$ & $0.17 \pm 0.01 \mathrm{a}-\mathrm{d}$ & $2.59 \pm 0.07 \mathrm{ab}$ & $0.105 \pm 0.007 \mathrm{a}$ \\
\hline 0.5 & - & 2.0 & - & $0.10 \pm 0.03 \mathrm{bc}$ & $0.08 \pm 0.05 \mathrm{~d}$ & $1.77 \pm 0.70 \mathrm{a}-\mathrm{c}$ & $0.027 \pm 0.004 \mathrm{bc}$ \\
\hline 0.5 & - & - & 0.5 & $0.25 \pm 0.03 \mathrm{a}-\mathrm{c}$ & $0.12 \pm 0.02 b-d$ & $2.16 \pm 0.20 \mathrm{a}-\mathrm{c}$ & $0.065 \pm 0.007 \mathrm{ab}$ \\
\hline 0.5 & - & - & 2.0 & $0.43 \pm 0.07 \mathrm{a}$ & $0.26 \pm 0.12 \mathrm{a}$ & $2.17 \pm 0.15 \mathrm{a}-\mathrm{c}$ & $0.098 \pm 0.006 \mathrm{a}$ \\
\hline 2.0 & - & 0.5 & - & $0.36 \pm 0.04 \mathrm{a}$ & $0.11 \pm 0.01 \mathrm{~b}-\mathrm{d}$ & $3.31 \pm 0.24 \mathrm{a}$ & $0.094 \pm 0.010 \mathrm{a}$ \\
\hline 2.0 & - & 2.0 & - & $0.12 \pm 0.01 \mathrm{bc}$ & $0.09 \pm 0.02 \mathrm{~cd}$ & $1.66 \pm 0.44 \mathrm{a}-\mathrm{c}$ & $0.035 \pm 0.003 \mathrm{bc}$ \\
\hline 2.0 & - & - & 0.5 & $0.40 \pm 0.04 \mathrm{a}$ & $0.16 \pm 0.01 \mathrm{a}-\mathrm{d}$ & $2.61 \pm 0.41 \mathrm{ab}$ & $0.104 \pm 0.008 \mathrm{a}$ \\
\hline 2.0 & - & - & 2.0 & $0.34 \pm 0.01 \mathrm{ab}$ & $0.22 \pm 0.01 \mathrm{ab}$ & $1.57 \pm 0.07 \mathrm{bc}$ & $0.081 \pm 0.003 \mathrm{ab}$ \\
\hline- & 0.5 & 0.5 & - & $0.28 \pm 0.02 \mathrm{ab}$ & $0.16 \pm 0.03 \mathrm{a}-\mathrm{d}$ & $2.10 \pm 0.54 \mathrm{a}-\mathrm{c}$ & $0.077 \pm 0.009 \mathrm{ab}$ \\
\hline- & 0.5 & 2.0 & - & $0.26 \pm 0.05 \mathrm{a}-\mathrm{c}$ & $0.12 \pm 0.01 \mathrm{~b}-\mathrm{d}$ & $2.17 \pm 0.52 \mathrm{a}-\mathrm{c}$ & $0.061 \pm 0.015 \mathrm{a}-\mathrm{c}$ \\
\hline- & 0.5 & - & 0.5 & $0.41 \pm 0.07 \mathrm{a}$ & $0.20 \pm 0.01 \mathrm{a}-\mathrm{c}$ & $1.98 \pm 0.33 \mathrm{a}-\mathrm{c}$ & $0.095 \pm 0.019 \mathrm{a}$ \\
\hline- & 0.5 & - & 2.0 & $0.43 \pm 0.05 \mathrm{a}$ & $0.17 \pm 0.01 \mathrm{a}-\mathrm{d}$ & $2.42 \pm 0.16 \mathrm{ab}$ & $0.113 \pm 0.008 \mathrm{a}$ \\
\hline- & 2.0 & 0.5 & - & $0.29 \pm 0.06 \mathrm{ab}$ & $0.12 \pm 0.03 \mathrm{~b}-\mathrm{d}$ & $2.62 \pm 0.25 \mathrm{ab}$ & $0.079 \pm 0.014 \mathrm{ab}$ \\
\hline- & 2.0 & 2.0 & - & $0.26 \pm 0.02 \mathrm{a}-\mathrm{c}$ & $0.13 \pm 0.02 b-d$ & $2.01 \pm 0.15 \mathrm{a}-\mathrm{c}$ & $0.070 \pm 0.001 \mathrm{a}-\mathrm{c}$ \\
\hline- & 2.0 & - & 0.5 & $0.26 \pm 0.03 \mathrm{a}-\mathrm{c}$ & $0.13 \pm 0.02 b-d$ & $2.08 \pm 0.28 \mathrm{a}-\mathrm{c}$ & $0.070 \pm 0.008 \mathrm{a}-\mathrm{c}$ \\
\hline- & 2.0 & - & 2.0 & $0.08 \pm 0.01 \mathrm{c}$ & $0.12 \pm 0.01 \mathrm{~b}-\mathrm{d}$ & $0.63 \pm 0.03 \mathrm{c}$ & $0.014 \pm 0.003 \mathrm{c}$ \\
\hline \multicolumn{8}{|c|}{ White Gold } \\
\hline- & - & - & - & $0.26 \pm 0.02 \mathrm{a}-\mathrm{c}$ & $0.14 \pm 0.02 \mathrm{ab}$ & $1.85 \pm 0.16 \mathrm{ab}$ & $0.077 \pm 0.005 \mathrm{a}-\mathrm{c}$ \\
\hline 0.5 & - & 0.5 & - & $0.21 \pm 0.02 \mathrm{bc}$ & $0.11 \pm 0.01 \mathrm{~b}$ & $1.94 \pm 0.27 \mathrm{ab}$ & $0.062 \pm 0.001 \mathrm{bc}$ \\
\hline 0.5 & - & 2.0 & - & $0.16 \pm 0.03 \mathrm{c}$ & $0.14 \pm 0.04 \mathrm{ab}$ & $1.20 \pm 0.16 \mathrm{~b}$ & $0.039 \pm 0.001 \mathrm{c}$ \\
\hline 0.5 & - & - & 0.5 & $0.38 \pm 0.03 \mathrm{a}$ & $0.21 \pm 0.01 \mathrm{a}$ & $1.78 \pm 0.08 \mathrm{ab}$ & $0.105 \pm 0.005 \mathrm{a}$ \\
\hline 0.5 & - & - & 2.0 & $0.31 \pm 0.02 \mathrm{a}-\mathrm{c}$ & $0.18 \pm 0.01 \mathrm{ab}$ & $1.77 \pm 0.13 \mathrm{ab}$ & $0.081 \pm 0.005 \mathrm{a}-\mathrm{c}$ \\
\hline 2.0 & - & 0.5 & - & $0.30 \pm 0.02 \mathrm{a}-\mathrm{c}$ & $0.19 \pm 0.01 \mathrm{ab}$ & $1.56 \pm 0.10 \mathrm{ab}$ & $0.074 \pm 0.001 \mathrm{a}-\mathrm{c}$ \\
\hline 2.0 & - & 2.0 & - & $0.16 \pm 0.01 \mathrm{c}$ & $0.13 \pm 0.01 \mathrm{ab}$ & $1.23 \pm 0.19 b$ & $0.042 \pm 0.010 \mathrm{c}$ \\
\hline 2.0 & - & - & 0.5 & $0.34 \pm 0.03 \mathrm{ab}$ & $0.19 \pm 0.02 \mathrm{ab}$ & $1.81 \pm 0.09 \mathrm{ab}$ & $0.081 \pm 0.007 \mathrm{a}-\mathrm{c}$ \\
\hline 2.0 & - & - & 2.0 & $0.36 \pm 0.03 \mathrm{a}$ & $0.19 \pm 0.01 \mathrm{ab}$ & $1.91 \pm 0.07 \mathrm{ab}$ & $0.093 \pm 0.008 \mathrm{ab}$ \\
\hline- & 0.5 & 0.5 & - & $0.27 \pm 0.02 \mathrm{a}-\mathrm{c}$ & $0.12 \pm 0.01 \mathrm{ab}$ & $2.22 \pm 0.08 \mathrm{ab}$ & $0.074 \pm 0.006 \mathrm{a}-\mathrm{c}$ \\
\hline- & 0.5 & 2.0 & - & $0.23 \pm 0.00 \mathrm{a}-\mathrm{c}$ & $0.14 \pm 0.02 a b$ & $1.70 \pm 0.16 \mathrm{ab}$ & $0.062 \pm 0.010 \mathrm{bc}$ \\
\hline- & 0.5 & - & 0.5 & $0.31 \pm 0.03 \mathrm{a}-\mathrm{c}$ & $0.20 \pm 0.01 \mathrm{ab}$ & $1.58 \pm 0.02 \mathrm{ab}$ & $0.078 \pm 0.007 \mathrm{a}-\mathrm{c}$ \\
\hline- & 0.5 & - & 2.0 & $0.35 \pm 0.03 \mathrm{ab}$ & $0.17 \pm 0.02 \mathrm{ab}$ & $2.07 \pm 0.24 \mathrm{ab}$ & $0.087 \pm 0.007 \mathrm{a}-\mathrm{c}$ \\
\hline- & 2.0 & 0.5 & - & $0.24 \pm 0.01 \mathrm{a}-\mathrm{c}$ & $0.14 \pm 0.02 \mathrm{ab}$ & $1.80 \pm 0.33 \mathrm{ab}$ & $0.066 \pm 0.006 \mathrm{a}-\mathrm{c}$ \\
\hline- & 2.0 & 2.0 & - & $0.23 \pm 0.00 \mathrm{a}-\mathrm{c}$ & $0.15 \pm 0.00 \mathrm{ab}$ & $1.54 \pm 0.02 \mathrm{ab}$ & $0.063 \pm 0.001 \mathrm{a}-\mathrm{c}$ \\
\hline- & 2.0 & - & 0.5 & $0.35 \pm 0.04 \mathrm{ab}$ & $0.16 \pm 0.05 a b$ & $2.53 \pm 0.57 \mathrm{a}$ & $0.097 \pm 0.008 \mathrm{ab}$ \\
\hline- & 2.0 & - & 2.0 & $0.39 \pm 0.05 \mathrm{a}$ & $0.19 \pm 0.02 a b$ & $2.07 \pm 0.08 \mathrm{ab}$ & $0.096 \pm 0.012 \mathrm{ab}$ \\
\hline
\end{tabular}

${ }^{1}$ Means \pm standard errors in columns marked with the same letter do not differ significantly according to the HSD Tukey's test $(P \leq 0.05)$

* $B A$ 6-benzyladenine, IAA indole-3-acetic acid, IBA indole-3-butyric acid, KIN kinetin, $P G R$ plant growth regulator

MS medium with $2.0 \mathrm{mg} \cdot \mathrm{L}^{-1} \mathrm{IAA}$ and $2.0 \mathrm{mg} \cdot \mathrm{L}^{-1} \mathrm{KIN}$ or $0.5 \mathrm{mg} \cdot \mathrm{L}^{-1}$ IBA and $0.5 \mathrm{mg} \cdot \mathrm{L}^{-1} \mathrm{BA}$ or KIN, although other experimental combinations also provided good results $(50-80 \%$ survival rate). Plants, which survived acclimatization and were of best ('superb') quality started to develop new vigorous leaves in the second week of ex vitro growth (Table 5). Only 'Gold Heart' plants from three experimental combinations (including the control) were of poor quality after acclimatization with numerous dead leaves visible (Fig. 1e). 
Table 5 Influence of multiplication medium composition on the subsequent ex vitro acclimatization efficiency [\%] in L. spectabilis

\begin{tabular}{|c|c|c|c|c|c|c|c|}
\hline \multicolumn{4}{|c|}{ PGR $*$ concentration $\left[\mathrm{mg} \cdot \mathrm{L}^{-1}\right]$} & \multicolumn{2}{|l|}{ Gold Heart } & \multicolumn{2}{|l|}{ White Gold } \\
\hline IAA & IBA & BA & KIN & Survival [\%] & Shoot quality & Survival $[\%]$ & Shoot quality \\
\hline- & - & - & - & $20.0 \mathrm{bc}$ & + & $80.0 \mathrm{ab}$ & ++ \\
\hline 0.5 & - & 0.5 & - & $50.0 \mathrm{a}-\mathrm{c}$ & ++ & $50.0 \mathrm{ab}$ & ++ \\
\hline 0.5 & - & 2.0 & - & $50.0 \mathrm{a}-\mathrm{c}$ & +++ & $20.0 \mathrm{~b}$ & +++ \\
\hline 0.5 & - & - & 0.5 & $20.0 \mathrm{bc}$ & +++ & $20.0 \mathrm{~b}$ & ++ \\
\hline 0.5 & - & - & 2.0 & $80.0 \mathrm{ab}$ & ++ & $50.0 \mathrm{ab}$ & ++ \\
\hline 2.0 & - & 0.5 & - & $80.0 \mathrm{ab}$ & +++ & $80.0 \mathrm{ab}$ & ++ \\
\hline 2.0 & - & 2.0 & - & $80.0 \mathrm{ab}$ & +++ & $80.0 \mathrm{ab}$ & +++ \\
\hline 2.0 & - & - & 0.5 & $0.0 \mathrm{c}$ & + & $80.0 \mathrm{ab}$ & ++ \\
\hline 2.0 & - & - & 2.0 & $100 \mathrm{a}$ & +++ & $100 \mathrm{a}$ & ++ \\
\hline- & 0.5 & 0.5 & & $80.0 \mathrm{ab}$ & +++ & $100 \mathrm{a}$ & +++ \\
\hline- & 0.5 & 2.0 & & $50.0 \mathrm{a}-\mathrm{c}$ & +++ & $80.0 \mathrm{ab}$ & +++ \\
\hline- & 0.5 & - & 0.5 & $20.0 \mathrm{bc}$ & +++ & $100 \mathrm{a}$ & +++ \\
\hline- & 0.5 & - & 2.0 & $100 \mathrm{a}$ & +++ & $80.0 \mathrm{ab}$ & +++ \\
\hline- & 2.0 & 0.5 & - & $50.0 \mathrm{a}-\mathrm{c}$ & +++ & $80.0 \mathrm{ab}$ & +++ \\
\hline- & 2.0 & 2.0 & - & $0.0 \mathrm{c}$ & + & $20.0 \mathrm{~b}$ & +++ \\
\hline- & 2.0 & - & 0.5 & $20.0 \mathrm{bc}$ & +++ & $20.0 \mathrm{~b}$ & +++ \\
\hline- & 2.0 & - & $\begin{array}{l}2.0 \\
\text { Mean }\end{array}$ & $\begin{array}{l}50.0 \mathrm{a}-\mathrm{c} \\
50.0\end{array}$ & ++ & $\begin{array}{l}80.0 \mathrm{ab} \\
64.7\end{array}$ & +++ \\
\hline
\end{tabular}

${ }^{1}$ Means in columns marked with the same letter do not differ significantly according to the HSD Tukey's test $(P \leq 0.05)$

*BA 6-benzyladenine, IAA indole-3-acetic acid, IBA indole-3-butyric acid, KIN kinetin, $P G R$ plant growth regulator

+- poor quality, ++- fair quality, +++- superb quality

\section{Magnitude of Association Between the Variables Analyzed}

It was found that the proliferation ratio of shoots was negatively correlated with their length $(r=-0.35)$. Shoots produced in a higher number from a single explant also often contained less chlorophyll $a$ and carotenoids ( $r=-0.38$ and -0.40 , respectively). Similarly, increasing callogenesis efficiency and callus FWIDW had a negative impact on the content of the analyzed metabolites in the shoots (Table 6).

In contrast, there was a very strong positive association between the FW and DW in shoots $(r=0.84)$ and callus $(r=0.97)$. Experimental combinations which stimulated most frequent callus formation also positively affected its FW and DW (Table 6). Moreover, the FW and DW of callus were positively correlated with the number of shoots produced by a single explant. Longer shoots contained more chlorophyll $a(r=0.61)$ and carotenoids $(r=0.64)$. The concentration of carotenoids in tissues increased with the concentration of chlorophyll $a(\mathrm{r}=0.98)$ and $b(r=0.64)$, while the content of chlorophyll $a$ was positively correlated with the concentration of chlorophyll $b$. It was also found that the rooting rate, i.e., share of explants regenerating roots, was positively correlated with the root length and the number of roots regenerated per one explant $(r=0.80-0.90)$. Furthermore, plants with a higher number of leaves were more likely to survive acclimatization to ex vitro conditions (Table 6).

\section{Genetic Stability of In Vitro-Grown Shoots}

A total of 3770 scorable bands, in the range of 153 $-2,664 \mathrm{bp}$, were detected by 10 RAPD primers (Table 7). The highest number of loci (12) was amplified with the R-G primer, while 4 loci were found with the R-A primer. Primers R-A and R-B did not detect any polymorphisms. On the other hand, $71.4 \%$ of polymorphic loci (within three genotypes) were reported with the R-F primer. A total of 47 polymorphic plants were detected within the RAPD analysis.

The SCoT marker system generated nearly twice as many products than RAPD; 6,915 scorable bands, in the range of $211-3,000$ bp (Table 7). The greatest number of loci (21) was found with the S-E primer, while primers S-F and S-J amplified only 7 loci. The highest share of polymorphic loci was detected by the S-B primer (88.2\%). Polymorphic and/ or unique bands were found in 25 samples $(36.8 \%$ of all plants tested).

The tested plants were grouped into two clusters, according to the RAPD analysis (Fig. 2a). Four samples with the 
Table 6 Strength of association between the analyzed traits of plants, based on the Pearson correlation coefficient $(P \leq 0.05)$, regardless of cultivar

\begin{tabular}{|c|c|c|c|c|c|c|c|c|c|c|c|c|c|c|c|c|c|}
\hline \multicolumn{2}{|c|}{ Trait } & \multirow[t]{2}{*}{1} & \multirow[t]{2}{*}{2} & \multirow[t]{2}{*}{3} & \multirow[t]{2}{*}{4} & \multirow[t]{2}{*}{5} & \multirow[t]{2}{*}{6} & \multirow[t]{2}{*}{7} & \multirow[t]{2}{*}{8} & \multirow[t]{2}{*}{9} & \multirow[t]{2}{*}{10} & \multirow[t]{2}{*}{11} & \multirow[t]{2}{*}{12} & \multirow[t]{2}{*}{13} & \multirow[t]{2}{*}{14} & \multirow[t]{2}{*}{15} & \multirow[t]{2}{*}{16} \\
\hline 1 & No. of shoots & & & & & & & & & & & & & & & & \\
\hline 2 & No. of leaves & 0.82 & 1 & & & & & & & & & & & & & & \\
\hline 3 & Shoot length & -0.35 & ns & 1 & & & & & & & & & & & & & \\
\hline 4 & Callogenesis rate & ns & ns & ns & 1 & & & & & & & & & & & & \\
\hline 5 & Soot FW & 0.61 & 0.59 & $\mathrm{~ns}$ & ns & 1 & & & & & & & & & & & \\
\hline 6 & Shoot DW & 0.56 & 0.60 & ns & ns & 0.84 & 1 & & & & & & & & & & \\
\hline 7 & Callus FW & 0.52 & ns & ns & 0.77 & $\mathrm{~ns}$ & ns & 1 & & & & & & & & & \\
\hline 8 & Callus DW & 0.47 & ns & ns & 0.72 & ns & ns & 0.97 & 1 & & & & & & & & \\
\hline 9 & Rooting rate & ns & ns & $\mathrm{ns}$ & ns & ns & ns & ns & ns & 1 & & & & & & & \\
\hline 10 & No. of roots & ns & ns & ns & ns & ns & ns & $\mathrm{ns}$ & $\mathrm{ns}$ & 0.90 & 1 & & & & & & \\
\hline 11 & Root length & ns & ns & $\mathrm{ns}$ & $\mathrm{ns}$ & ns & ns & $\mathrm{ns}$ & ns & 0.80 & ns & 1 & & & & & \\
\hline 12 & Chlorophyll $a$ content & -0.38 & $\mathrm{~ns}$ & 0.61 & ns & $\mathrm{ns}$ & ns & -0.44 & -0.44 & ns & $\mathrm{ns}$ & $\mathrm{ns}$ & 1 & & & & \\
\hline 13 & Chlorophyll $b$ content & ns & $\mathrm{ns}$ & ns & -0.46 & ns & ns & -0.51 & -0.48 & ns & ns & $\mathrm{ns}$ & 0.72 & 1 & & & \\
\hline 14 & Carotenoids content & -0.40 & $\mathrm{~ns}$ & 0.64 & $\mathrm{~ns}$ & $\mathrm{~ns}$ & ns & -0.41 & -0.42 & ns & ns & $\mathrm{ns}$ & 0.98 & 0.64 & 1 & & \\
\hline 15 & Chlorophyll $a: b$ ratio & ns & $\mathrm{ns}$ & 0.77 & $\mathrm{~ns}$ & $\mathrm{~ns}$ & ns & ns & ns & ns & ns & $\mathrm{ns}$ & 0.62 & 0.68 & ns & 1 & \\
\hline 16 & Acclimatization rate & ns & 0.36 & ns & ns & $\mathrm{ns}$ & ns & ns & ns & ns & $\mathrm{ns}$ & ns & ns & $\mathrm{ns}$ & ns & ns & 1 \\
\hline
\end{tabular}

$D W$ dry weight, $F W$ fresh weight, $n s$ not significant

highest genetic distance (reaching up to 2.6) were placed in a single cluster, i.e., those derived from the media supplemented with $2.0 \mathrm{mg} \cdot \mathrm{L}^{-1} \mathrm{IBA}$ and $2.0 \mathrm{mg} \cdot \mathrm{L}^{-1} \mathrm{BA}$, $2.0 \mathrm{mg} \cdot \mathrm{L}^{-1} \mathrm{IBA}$ and $0.5 \mathrm{mg} \cdot \mathrm{L}^{-1} \mathrm{BA}, 2.0 \mathrm{mg} \cdot \mathrm{L}^{-1} \mathrm{IBA}$ and $0.5 \mathrm{mg} \cdot \mathrm{L}^{-1} \mathrm{KIN}, 0.5 \mathrm{mg} \cdot \mathrm{L}^{-1} \mathrm{IBA}$ and $2.0 \mathrm{mg} \cdot \mathrm{L}^{-1} \mathrm{KIN}$. The remaining 64 plants were arranged in the other cluster divided into 19 sub-clusters.

UPGMA analysis of SCoT markers also showed that the tested specimens were grouped into two clusters (Fig. 2b). One genotype produced on the medium with $2.0 \mathrm{mg} \cdot \mathrm{L}^{-1}$ IAA and $2.0 \mathrm{mg} \cdot \mathrm{L}^{-1} \mathrm{KIN}$ was markedly different from the others (genetic distance around 4.6). The remaining 67 plants were grouped into two sub-clusters, with a maximum genetic distance reaching 2.7 .

The PCoA analysis arranged the studied samples in three groups of uneven size, regardless of the genetic marker system used (Fig. 3). However, various plants were placed in those groups for RAPD and SCoT markers, respectively.

The AMOVA analysis revealed that $64 \%$ of the total genetic variation detected with the RAPD marker system is of interindividual origin, while $36 \%$ results from variation between groups (influence of PGRs). As for the SCoT markers, the culture medium composition was the source of $45 \%$ genetic variation among the population groups tested.

\section{Discussion}

\section{Morphogenetic Response of Explants}

Despite having immense importance, L. spectabilis has so far received inadequate attention regarding in vitro reproduction. The obtained results are cultivar-specific, which is in agreement with other ornamental plant species (Shri et al. 2006). Interestingly, in the present study, none of the tested 16 combinations of auxins and cytokinins improved significantly the morphological parameters or multiplication ratio of bleeding heart 'Gold Heart' compared to the PGRs-free control. Some combinations, i.e., those containing $2.0 \mathrm{mg} \cdot \mathrm{L}^{-1} \mathrm{IAA}$ or IBA and $2.0 \mathrm{mg} \cdot \mathrm{L}^{-1} \mathrm{BA}$ or $\mathrm{KIN}$, even had a deleterious effect on the shoot length, suggesting that elevating the concentration of PGRs in the culture medium is not favorable with this cultivar. Further research is needed to reveal the endogenous mechanisms of PGRs in L. spectabilis 'Gold Heart'. Nonetheless, the observed here multiplication ratio (up to 5.9) is quite high and similar to that reported in Ficus benjamina L. 'Natasha' and Heuchera $\times$ hybrida 'Florists Choice' (Miler et al. 2019).

An optimal culture medium composition has been identified with bleeding heart 'White Gold'. The MS medium supplemented with $0.5 \mathrm{mg} \cdot \mathrm{L}^{-1} \mathrm{IBA}$ and $2.0 \mathrm{mg} \cdot \mathrm{L}^{-1} \mathrm{BA}$ provided the highest number of shoots, leaves, and multiplication ratio (9.8) per one inoculated nodal segment. Auxins and cytokinins are the most essential PGRs, interacting in the regulation of cell proliferation and differentiation (Gaspar et al. 1996), which also explains the induction of 


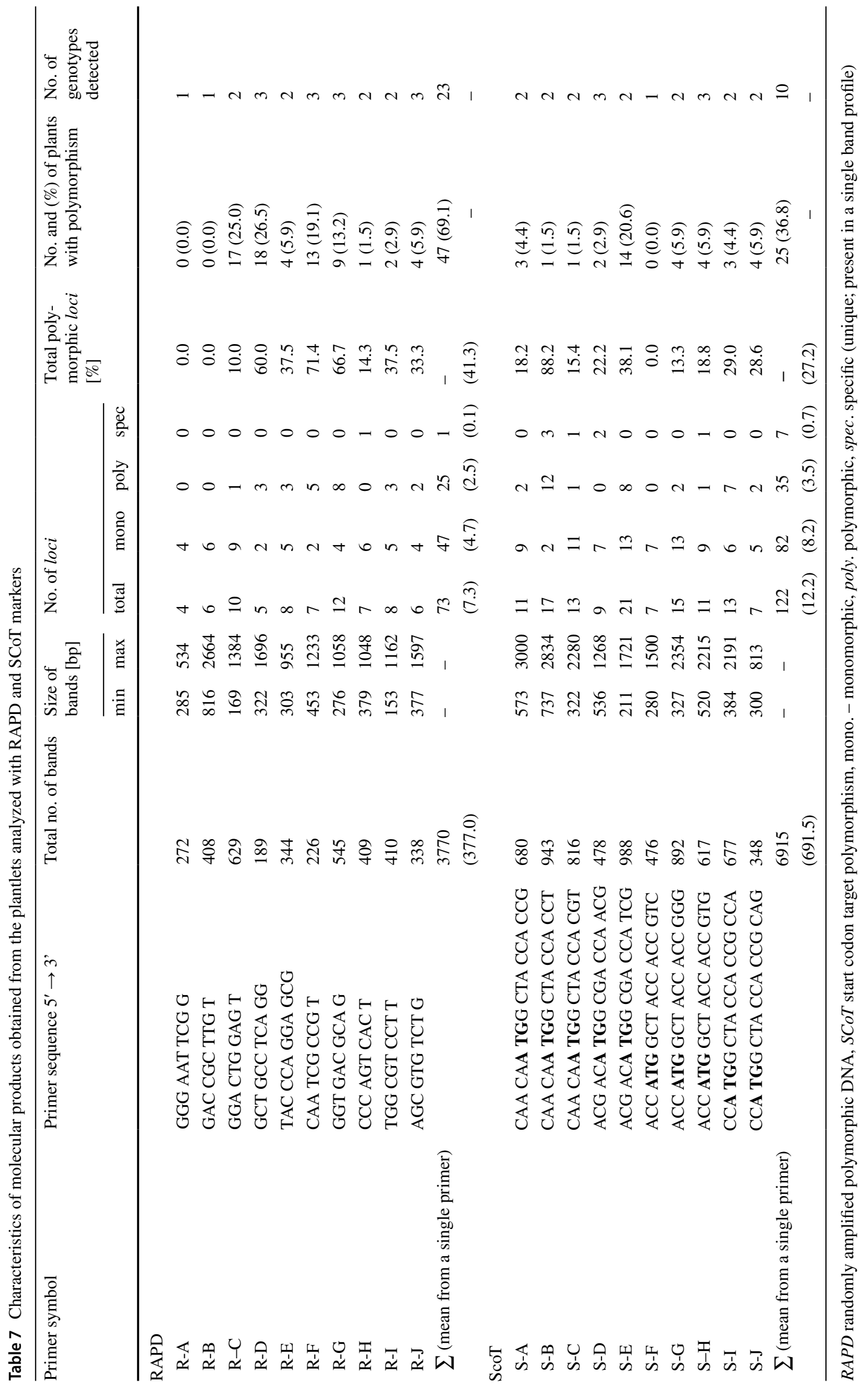


Fig. 2 Dendrograms based on the estimation of genetic distance coefficient and UPGMA clustering presenting the relationships between plants from different experimental combinations, revealed by the randomly amplified polymorphic DNA (RAPD; a and start codon sequence repeats (SCOT; b analyses. Samples representing the same band pattern as the predominant control plants are collected within a single group named 'Monomorphic'. The scale shows a real genetic distance value. $B A$ 6-benzyladenine, $I A A$ indole-3-acetic acid, $I B A$ indole-3-butyric acid, KIN kinetin $\left[\mathrm{mg} \cdot \mathrm{L}^{-1}\right]$

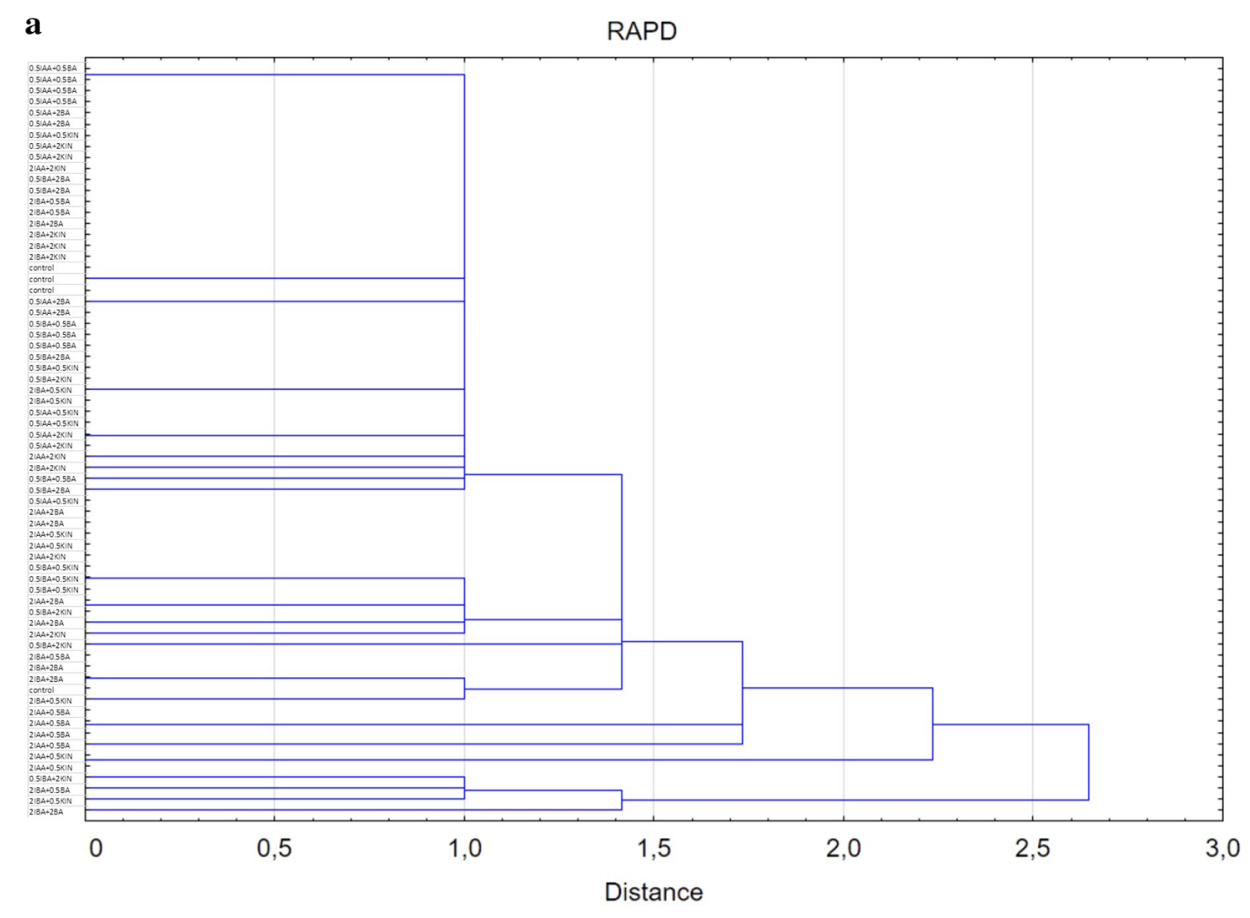

b

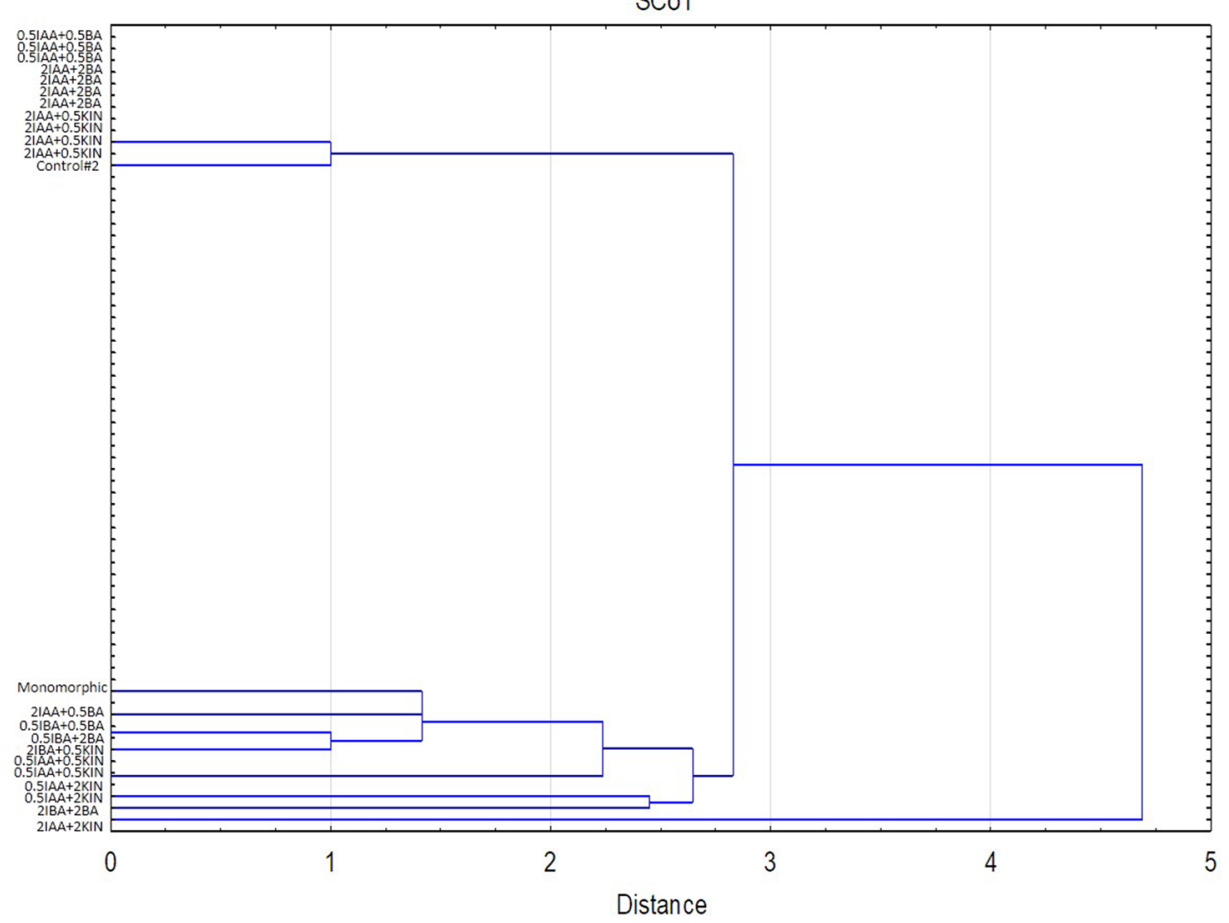

meristematic activity in L. spectabilis 'White Gold'. The obtained here proliferation efficiency (4.0 new shoots per one explant) is higher than that in Rosa rugosa Thunb. 'Tang Red' (3.0) and identical with $R$. rugosa 'Purple Branch' (4.0) (Xing et al. 2010). The share of DW in shoots was on a standard level in most of the tested experimental combinations, reaching from $12.2 \%$ to even $29.0 \%$. Moreover, there was a strong positive correlation between the FW and DW $(r=0.84)$, suggesting the good quality of shoots. Only in a few PGR combinations, the share of FW fell below 10\% suggesting a hyperhydration of shoots. Therefore, the described here medium, with $0.5 \mathrm{mg} \cdot \mathrm{L}^{-1} \mathrm{IBA}$ and $2.0 \mathrm{mg} \cdot \mathrm{L}^{-1} \mathrm{BA}$, can be recommended for large-scale multiplication of L. spectabilis 'White Gold'.

Callus development at the base of shoots was reported in most of the experimental combinations tested, especially in 
Fig. 3 Graphs of principal coordinates analysis (PCoA) of Lamprocapnos spectabilis 'White Gold' plants produced in different culture media, based on randomly amplified polymorphic DNA (RAPD; $\mathbf{a}$ and start codon sequence repeats (SCoT; b analyses. Samples representing the same band pattern as the predominant control plants are collected within a single group named 'Monomorphic' (part b). BA 6-benzyladenine, IAA indole-3-acetic acid, $I B A$ indole-3-butyric acid, KIN kinetin $\left[\mathrm{mg} \cdot \mathrm{L}^{-1}\right]$

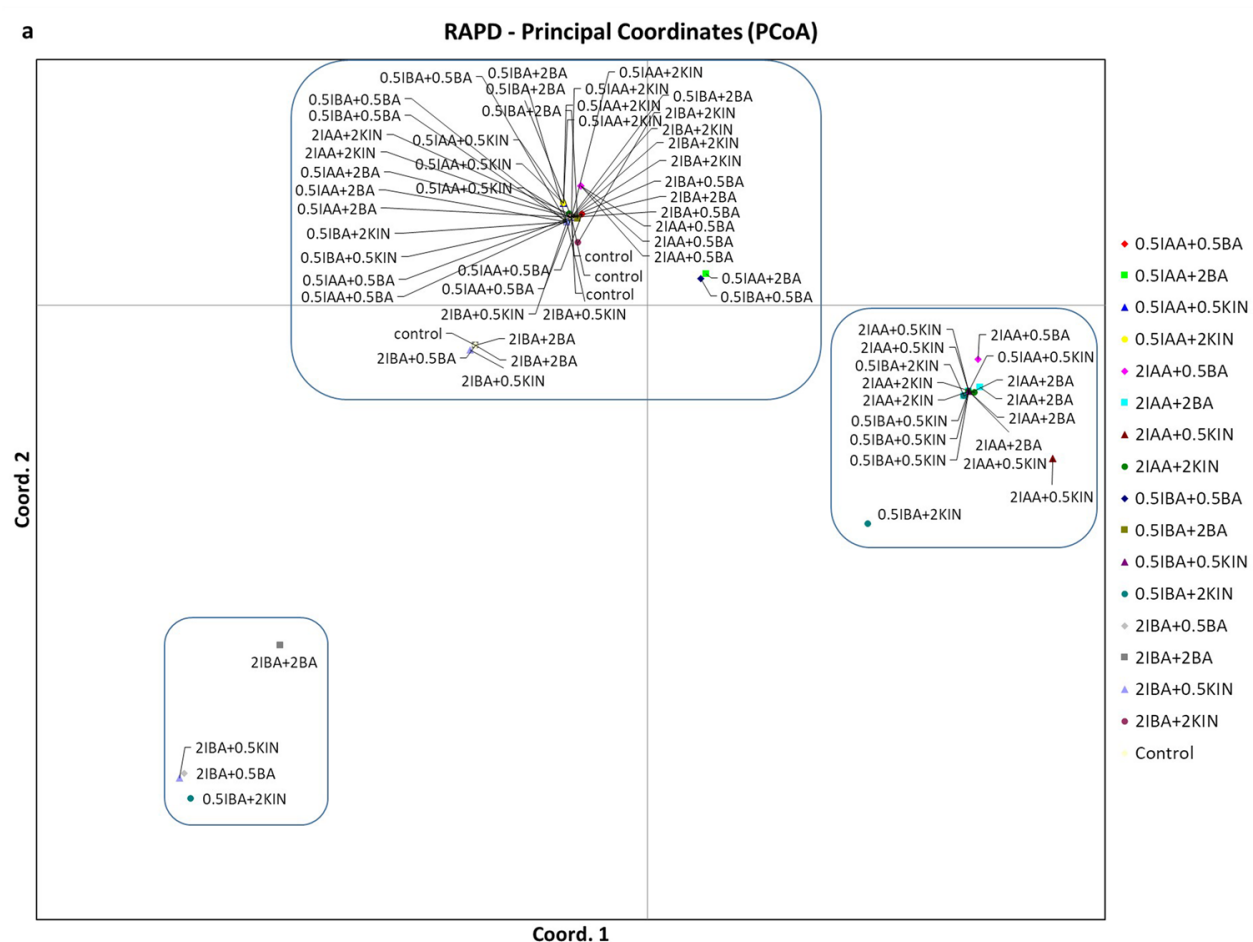

b SCoT - Principal Coordinates (PCOA)

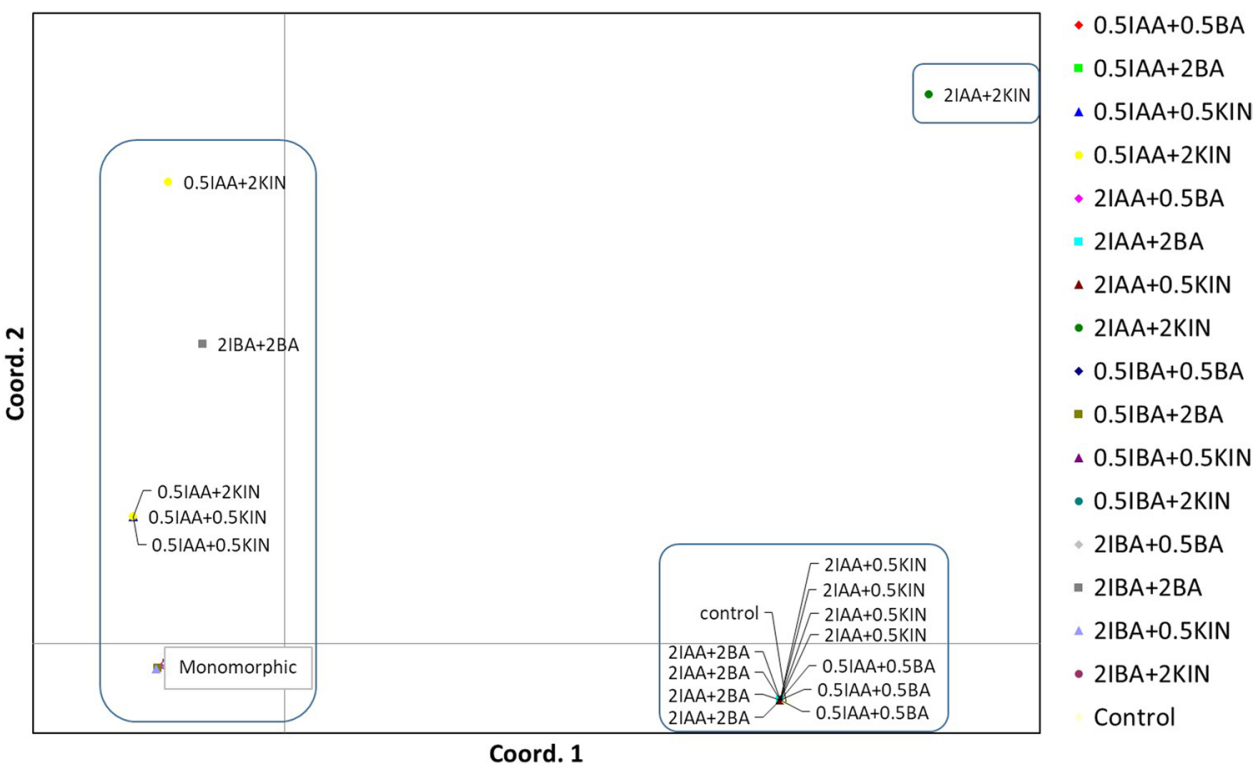

bleeding heart 'Gold Heart'. Callogenesis efficiency in the 'White Gold' cultivar was higher in the presence of IBA (79.7\% of explants) compared to IAA $(25.0 \%)$. A combination of $0.5 \mathrm{mg} \cdot \mathrm{L}^{-1} \mathrm{IBA}$ and $2.0 \mathrm{mg} \cdot \mathrm{L}^{-1} \mathrm{BA}$ stimulated the most abundant callus formation (427.6 mg FW per explant). On the other hand, Kaviani and Kazemi (2017) reported that medium with $1.0 \mathrm{mg} \cdot \mathrm{L}^{-1} \mathrm{BA}$ and $0.3 \mathrm{mg} \cdot \mathrm{L}^{-1} \mathrm{NAA}$ yielded in the highest formation of callus $(516 \mathrm{mg})$ from Petunia $\times$ hybrida hort. ex Vilm leaf culture. This underlines the great impact of the genetic factor on callogenesis.
Rooting is an integral step of most micropropagation protocols. Root system development is necessary for the survival and further growth of plants in the glasshouse. This developmental phenomenon involves the redifferentiation of predetermined cells and the initiation of several new meristematic areas (root primordia) in different tissues of stem cuttings (Yan et al. 2014). Some cultivars or plant species are capable of the simultaneous shoot and root development in vitro without an additional subculture, e.g., Kalanchoe tubiflora (Harvey) Hamet. (Kulus 
2015b). Usually, however, an additional rooting step in vitro (Xing et al. 2010) or ex vitro (Miler and Woźny 2016) is required as cytokinins inhibit rhizogenesis. In contrast, the promotion of adventitious root formation has been considered as one of the characteristics of auxins. Similarly, in the present study, the shoots of Lamprocapnos spectabilis were unable to regenerate roots in most of the multiplication media tested $(0-25 \%$ rooting efficiency and a maximum $42.9-62.5 \%$ in two experimental combinations). The medium supplemented solely with NAA, on the other hand, was efficient in stimulating rhizogenesis, as reported in other plant species (Yan et al. 2014). Further efforts should focus on achieving simultaneous rooting and acclimatization ex vitro, e.g., by soaking the shoots in the NAA solution for a predefined duration, to reduce labor and material costs.

\section{Biochemical Stability}

Production of bioactive metabolites from intact plants may be complex, due to several factors such as the impurity, heterogeneity, and inconsistency of the compounds produced. This can be improved by upgrading the in vitro culture systems (Raj et al. 2015). Several studies have reported that the type and concentration of PGRs affect the accumulation of metabolites in plant tissue culture systems (GrzegorczykKarolak et al. 2015, 2016). However, the exact mechanism of how growth regulators affect the biosynthesis of metabolites in plants is still not fully understood. None of the 16 media combinations tested in the present study enhanced significantly the content of chlorophylls or carotenoids in the shoots of Lamprocapnos spectabilis. Some of them even had a negative impact on those parameters compared to the control. This is surprising as cytokinins play an important role in the development and structural differentiation of plastids under in vitro culture (Dobránszki and Mendler-Drienyovszki 2014). For example, Cioć et al. (2019) reported a higher concentration of carotenoids $\left(0.14-0.16 \mathrm{mg} \cdot \mathrm{g}^{-1} \mathrm{FW}\right)$ in the leaves of Gerbera jamesonii Bolus microporpagated on the medium with an increased BA content. In the study with shoot culture of Scutellaria altissima, thidiazuron (TDZ) was most effective among other tested cytokinins in promoting secondary metabolite synthesis (Grzegorczyk-Karolak et al. 2016). Alterations in the carbon cycle, low activity of key enzymes, as well as an irregular transport mechanism and catabolism caused by in vitro culture stress may explain the low production of metabolites in Lamprocapnos spectabilis (Nitnaware et al. 2011). Especially the secretion of phenols into the medium might have caused this adverse phenomenon.

Further studies should focus on establishing an optimized protocol that can yield sustainable secondary metabolite production in L. spectabilis, at a minimal capital and operating costs. The addition of ascorbic acid (or any other antioxidant) into the medium to prevent phenols secretion could be a significant improvement. According to GrzegorczykKarolak et al. (2016), undifferentiated callus and cell suspension cultures of Scutellaria alpina showed higher amounts of metabolites than the proliferating shoot cultures. Therefore, this system could also be implemented with bleeding heart, especially that in the present study, callus development had a significant impact on the content of chlorophylls and carotenoids in the shoots of both cultivars tested (Table 6).

\section{Genetic Stability}

The current study is the first to analyze the genetic stability of Lamprocapnos spectabilis micropropagated in vitro. Polymorphic bands were detected in even $69.1 \%$ of plants studied. Based on the UPGMA and PCoA analyses, it can be assumed that most of the detected variation was minor and non-significant. Only four genotypes were distinctively different among the analyzed 68 plants. Callus development may be the reason for those alternations. PGRs, BA and callus-inducing auxins, in particular, are known to occasionally induce variation in micropropagated plants (Miler and Zalewska 2014). Another explanation may be the freeradical mechanism. According to Cassells and Curry (2001), much of the variability expressed in microshoots may be related to oxidative stress damage caused during explant isolation and, in culture, due to an altered oxygen regime. Abundant secretion of polyphenols reported in the following study may be a symptom supporting this hypothesis. Somaclonal variation was found and sometimes even utilized in the creation of new cultivars of chrysanthemum (Miler and Zalewska 2014), sugarcane (Francischini et al. 2017), and many other plant species (Krishna et al. 2016). However, not often such a high polymorphic ratio can be found (Karp 1995; Vitamvas et al. 2019). The obtained results underline the susceptibility of bleeding heart to the action of DNA-affecting agents. Bleeding heart 'White Gold' can be, therefore, considered a good model organism for mutation breeding studies.

The present study demonstrated a higher discriminatory power of RAPD genetic markers (polymorphisms detected in 47 plants) compared to SCoT (polymorphisms found in 25 samples). It was also found that different primers detected variation in different plants. Various genetic markers explore different regions of the genome that have specific evolutionary patterns, which could explain the reported here differences. Another explanation is that SCoT explores only coding sequences, while RAPD also surveys noncoding sequences (Nadeem et al. 2018). Kulus et al. (2019) also confirmed the higher effectiveness of RAPDs in detecting variation in chrysanthemum, compared to inter-simple sequence repeats (ISSRs). On the other hand, in the study 
by Fernández et al. (2002) and Zhnag et al. (2013), RAPDs were less successful in distinguishing genotypes compared to other marker types. It is possible that for species of the Fumariaceae family, RAPD markers are characterized by a high level of polymorphisms.

\section{Acclimatization and Ex Vitro Growth}

The quality and physiological state of micropropagated shoots are of great importance when transferring the plantlets from artificial in vitro (mixotrophic) to natural, ex vitro (autotrophic) conditions. Exogenous factors, such as culture medium components, affect the photosynthetic apparatus of the in vitro-derived plantlets (Dobránszki and MendlerDrienyovszki 2014). Consequently, in the present study, the acclimatization efficiency reached from 0.0 to $100 \%$, depending on the PGRs composition. The reported here mean survival rate $(50.0-64.7 \%$, depending on the cultivar) is comparable to that reported by Lee et al. (2004) with wild Dicentra spectabilis Lem. (58\%). Plants that did not survive the ex vitro transfer possibly had a dysfunctional photosynthetic apparatus, e.g., deformed or constantly open stomata, enlarged intercellular spaces, lack of cuticle, etc. This is a common problem in micropropagation, resulting from the unnatural environment in vitro (Hazarika 2003). Microshoots with a higher number of leaves were more likely to survive acclimatization, probably due to a higher photosynthetic activity.

There was also a difference in the quality of plants found, depending on their origin. The presence of IBA in the multiplication medium seemed to be favorable with bleeding heart 'White Gold'. Plants derived from all eight experimental combinations including this auxin were of superior quality after transplanting to the glasshouse compared to those produced on the IAA-supplemented medium-mostly fair quality. IBA is well known for improving the quality of micropropagated plants. It is an auxin precursor with a variety of different effects on plant growth and development; not only rooting (Frick and Strader 2017). On the other hand, there was no clear influence of the multiplication medium composition on the quality of 'Gold Heart' plants after acclimatization, although, most of the plants produced in the presence of PGRs were of better quality (fair or superb) compared to the control (poor quality). This also can be attributed to the impact of auxins and cytokinins on the plant expansion and photosynthetic activity (Dobránszki and Mendler-Drienyovszki 2014).

The observed here $100 \%$ survival rate in several experimental combinations, together with the superb quality of plants, are very satisfying as it is quite difficult to produce plants that can be acclimatized to the outdoor environment without any loss (Hazarika 2003). Therefore, the described here protocols can be recommended for large-scale production of Lamprocapnos spectabilis.

\section{Conclusion}

This study developed a simple and practical micropropagation protocol for Lamprocapnos spectabilis, using common and affordable plant growth regulators. Separating the shoot multiplication and rooting steps seem necessary in bleeding heart. Culture medium fortified with $0.5 \mathrm{mg} \cdot \mathrm{L}^{-1} \mathrm{IBA}$ and $2.0 \mathrm{mg} \cdot \mathrm{L}^{-1} \mathrm{BA}$ is recommended for the multiplication of bleeding heart 'White Gold', whereas a PGRs-free medium can be utilized with the 'Gold Heart' cultivar (although, not directly before acclimatization). Shoots produced in those media are stable on the biochemical level. Those combinations are also securing the genetic integrity of $L$. spectabilis. Other compositions of plant growth regulators, however, can be a source of lesser or greater genetic variability. The species can be quite easily acclimatized to ex vitro conditions, after rooting in an NAA-supplemented medium, providing high-quality plant material for the ornamental and pharmaceutical markets. Moreover, due to the quite high susceptibility to somaclonal variation occurrence, Lamprocapnos spectabilis 'White Gold' might be a good model plant for mutation breeding research.

Acknowledgements The authors wish to thank Mrs. Zeynep Demirtaş for technical support in performing this research.

Author contributions DK: Conceptualization, Methodology, Resources, Writing—original draft preparation, Writing—review and editing, Visualization, Supervision; DK, JDM, and BA: Investigation, Data curation, validation, and analysis.

\section{Compliance with Ethical Standards}

Conflict of interest On behalf of all authors, the corresponding author states that there is no conflict of interest.

Open Access This article is licensed under a Creative Commons Attribution 4.0 International License, which permits use, sharing, adaptation, distribution and reproduction in any medium or format, as long as you give appropriate credit to the original author(s) and the source, provide a link to the Creative Commons licence, and indicate if changes were made. The images or other third party material in this article are included in the article's Creative Commons licence, unless indicated otherwise in a credit line to the material. If material is not included in the article's Creative Commons licence and your intended use is not permitted by statutory regulation or exceeds the permitted use, you will need to obtain permission directly from the copyright holder. To view a copy of this licence, visit http://creativecommons.org/licenses/by/4.0/. 


\section{References}

Cassells AC, Curry RF (2001) Oxidative stress and physiological, epigenetic and genetic variability in plant tissue culture: Implications for micropropagators and genetic engineers. Plant Cell Tissue Organ Cult 64(2-3):145-157. https://doi.org/10.1023/A:10106 92104861

Cioć M, Kalisz A, Żupnik M, Pawłowska B (2019) Different LED light intensities and 6-benzyladenine concentrations in relation to shoot development, leaf architecture, and photosynthetic pigments of Gerbera jamesonii Bolus in vitro. Agronomy 9:358. https://doi. org/10.3390/agronomy9070358www.mdpi.com/journal/agronomy

Dobránszki J, Mendler-Drienyovszki N (2014) Cytokinin-induced changes in the chlorophyll content and fluorescence of in vitro apple leaves. J Plant Physiol 171:1472-1478. https://doi. org/10.1016/j.jplph.2014.06.015

Fernández ME, Figueiras AM, Benito C (2002) The use of ISSR and RAPD markers for detecting DNA polymorphism, genotype identification and genetic diversity among barley cultivars with known origin. Theor Appl Genet 104(5):845-851. https://doi. org/10.1007/s00122-001-0848-2

Francischini JHMB, Kemper EL, Costa JB, Manechini JRV, Pinto LR (2017) DNA methylation in sugarcane somaclonal variants assessed through methylation-sensitive amplified polymorphism. Genet Mol Res. https://doi.org/10.4238/gmr16029585

Frick EM, Strader LC (2017) Roles for IBA-derived auxin in plant development. J Exp Bot 69(2):169-177. https://doi.org/10.1093/ jxb/erx298

Gaspar T, Kevers C, Penel C, Greppin H, Reid DM, Thorpeet TA (1996) Plant hormones and plant growth regulators in plant tissue culture. Vitro Cell Dev Biol Plant 32(4):272-289. https://doi. org/10.1007/BF02822700

Grzegorczyk-Karolak I, Kuźma Ł, Wysokińska H (2015) The effect of cytokinins on shoot proliferation, secondary metabolite production and antioxidant potential in shoot cultures of Scutellaria alpine. Plant Cell Tissue Organ Cult 122(3):699-708. https://doi. org/10.1007/s11240-015-0804-5

Grzegorczyk-Karolak I, Kuźma Ł, Wysokińska H (2016) In vitro cultures of Scutellaria alpina as a source of pharmacologically active metabolites. Acta Physiol Plant 38:7. https://doi.org/10.1007/ s11738-015-2024-3

Hazarika PN (2003) Acclimatization of tissue-cultured plants. Curr Sci 85(12):1704-1712

Hodges L (2012) Bleeding heart: A review for growers. Hort Technol 22(4):517-522

Iwasa K, Kim C-W (1997) Biotransformations of protoberberines in cell cultures of Dicentra spectablis. Phytochem 46(8):1359-1363

Joshi R, Kumar P (2013) Regulation of somatic embryogenesis in crops: A review. Agric Rev 34(1):1-20

Karp A (1995) Somaclonal variation as a tool for crop improvement. Euphytica 85:295-302

Kaviani B, Kazemi D (2017) Callus induction and organogenesis capacity from lamina explant of Petunia $\times$ hybrida F1 induced by BA and NAA. J Ornam Plants 7(3):157-162

Krishna H, Alizadeh M, Singh D, Singh U, Chauhan N, Eftekhari M, Sadh RK (2016) Somaclonal variations and their applications in horticultural crops improvement. 3 Biotech 6(1):54. https://doi. org/10.1007/s13205-016-0389-7

Kulus D (2015a) Selected aspects of ornamental plants micropropagation in Poland and worldwide. Life Sci 4(10):10-25. https://doi. org/10.13140/RG.2.1.5086.8082

Kulus D (2015b) Micropropagation of Kalanchoe tubiflora (Harvey) Hamet. Sci Nat Technol 9(1):14. https://doi.org/10.17306 /J.NPT.2015.1.14
Kulus D (2020a) Influence of growth regulators on the development, quality, and physiological state of in vitro-propagated Lamprocapnos spectabilis (L.) Fukuhara. Vitro Cell Dev Biol Plant. https:// doi.org/10.1007/s11627-020-10064-1

Kulus D (2020b) Shoot tip cryopreservation of Lamprocapnos spectabilis (L.) Fukuhara using different approaches and evaluation of stability on the molecular, biochemical, and plant architecture levels. Int J Mol Sci 21(11):3901. https://doi.org/10.3390/ijms2 1113901

Kulus D, Rewers M, Serocka M, Mikuła A (2019) Cryopreservation by encapsulation-dehydration affects the vegetative growth of chrysanthemum but does not disturb its chimeric structure. Plant Cell Tiss Org 138(1):153-166. https://doi.org/10.1007/s1124 0-019-01614-6

Lee KP (2003) Lee DW (2003) Somatic embryogenesis and plant regeneration from seeds of wild Dicentra spectabilis (L.) Lem. Plant Cell Rep 22:105-109. https://doi.org/10.1007/s0029 9-003-0642-5

Lee K-S, Sim O-K, Shin J-S, Choi Y-E, Kim E-Y (2004) Mass propagation of Dicentra spectabilis L. Lemaire through in vitro suspension culture. J Plant Biotechnol 31(2):121-126

Lichtenthaler HK (1987) Chlorophylls and carotenoids: Pigments of photosynthetic biomembranes. Met Enzymol 148:350-382

Lichtenthaler HK, Buschmann C (2001) Chlorophylls and carotenoids: Measurement and characterization by UV VIS spectroscopy. Curr Prot Food Analyt Chem 1(1):F4.3.1-F4.3.8

Lucchesini M, Bertoli A, Mensuali-Sodi A, Pistelli L (2009) Establishment of in vitro tissue cultures from Echinacea angustifolia D.C. adult plants for the production of phytochemical compounds. Sci Hortic 122(3):484-490. https://doi.org/10.1016/j. scienta.2009.06.011

McNulty J, Poloczek J, Larichev V, Werstiuk NH, Griffin C, Pandey S (2007) Discovery of the apoptosis-inducing activity and high accumulation of the butenolides, menisdaurilide and aquilegiolide in Dicentra spectabilis. Planta Med 73:1543-1547. https://doi. org/10.1055/s-2007-990264

Miler N, Kulus D, Woźny A, Rymarz D, Hajzer M, Wierzbowski K, Nelke R, Szeffs L (2019) Application of wide-spectrum lightemitting diodes in micropropagation of popular ornamental plant species: A study on plant quality and cost reduction. Vitro Cellular and Developmental Biology Plant 55:99-108

Miler N, Woźny A (2016) LEDs application in ex vitro rooting and acclimatization of chrysanthemum (Chrysanthemum $\times$ grandiflorum /Ramat/Kitam). Electr J Pol Agric Univ 19(4):art02

Miler N, Zalewska M (2014) Somaclonal variation of chrysanthemum propagated in vitro from different explant types. Acta Sci Pol, Hort Cult 13(2):69-82

Murashige T, Skoog F (1962) A revised medium for rapid growth and bio assays with tobacco tissue cultures. Physiol Plant 15:473-497. https://doi.org/10.1111/j.1399-3054.1962.tb08052.x

Nadeem MA, Nawaz MA, Shahid MQ, Doğan Y, Comertpay G, Yıldız M, Hatipoğlu R, Ahmad F, Alsaleh A, Labhane N, Özkan H, Chung G, Baloch FS (2018) DNA molecular markers in plant breeding: current status and recent advancements in genomic selection and genome editing. Biotechnol Biotechnol Equip 32(2):261-285. https://doi.org/10.1080/13102818.2017.1400401

Nitnaware KM, Naik DG, Nikam TD (2011) Thidiazuron-induced shoot organogenesis and production of hepatoprotective lignan phyllanthin and hypophyllanthin in Phyllanthus amarus. Plant Cell Tissue Organ Cult 104:101. https://doi.org/10.1007/s1124 0-010-9796-3

Peakall R, Smouse PE (2012) GenAlEx 6.5: genetic analysis in Excel. Population genetic software for teaching and research-an update. Bioinformatics 28:2537-2539. https://doi.org/10.1093/bioinforma tics/bts460 
Raj D, Kokotkiewicz A, Drys A, Luczkiewicz, (2015) Effect of plant growth regulators on the accumulation of indolizidine alkaloids in Securinega suffruticosa callus cultures. Plant Cell Tissue Organ Cult 123:39-45. https://doi.org/10.1007/s11240-015-0811-6

Shri M, Jain SM, Jenks MA, Rout GR, Radojević L (2006) Micropropagation of ornamental potted plants. Prop Ornam Plants 6(2):67-82

Simon S, Petrášek P (2011) Why plants need more than one type of auxin. Plant Sci 180(3):454-460. https://doi.org/10.1016/j.plant sci.2010.12.007

Vitamvas J, Viehmannova I, Cepkova PH, Mrhalova H, Eliasova K (2019) Assessment of somaclonal variation in indirect morphogenesis-derived plants of Arracacia xanthorrhiza. Pesq Agropec Bras 54:e00301. https://doi.org/10.1590/s1678-3921.pab20 19.v54.00301

Xing W, Bao M, Qin H, Ning G (2010) Micropropagation of Rosa rugosa through axillary shoot proliferation. Acta Biol
Cracoviensia s Bot 52(2):69-75. https://doi.org/10.2478/v1018 2-010-0025-5

Yan Y-H, Li J-L, Zhang X-Q, WanMa Y-YY, Zhu Y-M, Peng Y-Q, Huang Y (2014) Effect of naphthalene acetic acid on adventitious root development and associated physiological changes in stem cutting of Hemarthria compressa. PLoS ONE 9(3):e90700. https ://doi.org/10.1371/journal.pone.0090700

Zhang L, Zhang HG, Li XF (2013) Analysis of genetic diversity in Larix gmelinii (Pinaceae) with RAPD and ISSR markers. Genet Mol Res 12(1):196-207. https://doi.org/10.4238/2013.Janua ry. 24.12

Publisher's Note Springer Nature remains neutral with regard to jurisdictional claims in published maps and institutional affiliations. 